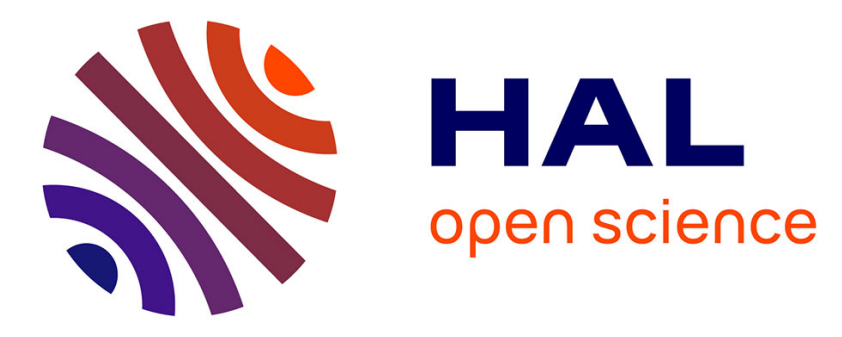

\title{
Evaluation of cationic core-shell thermoresponsive poly(N-vinylcaprolactam)-based microgels as potential drug delivery nanocarriers
}

Laura Etchenausia, Eva Villar-Alvarez, Jacqueline Forcada, Maud Save, Pablo Taboada

\section{To cite this version:}

Laura Etchenausia, Eva Villar-Alvarez, Jacqueline Forcada, Maud Save, Pablo Taboada. Evaluation of cationic core-shell thermoresponsive poly(N-vinylcaprolactam)-based microgels as potential drug delivery nanocarriers. Materials Science and Engineering: C, 2019, 104, pp.109871. 10.1016/j.msec.2019.109871 . hal-02152899

\section{HAL Id: hal-02152899 \\ https://hal.science/hal-02152899}

Submitted on 27 Oct 2020

HAL is a multi-disciplinary open access archive for the deposit and dissemination of scientific research documents, whether they are published or not. The documents may come from teaching and research institutions in France or abroad, or from public or private research centers.
L'archive ouverte pluridisciplinaire HAL, est destinée au dépôt et à la diffusion de documents scientifiques de niveau recherche, publiés ou non, émanant des établissements d'enseignement et de recherche français ou étrangers, des laboratoires publics ou privés. 


\section{Evaluation of cationic core-shell thermoresponsive poly $(\mathrm{N}$ - vinylcaprolactam)-based microgels as potential drug delivery nanocarriers}

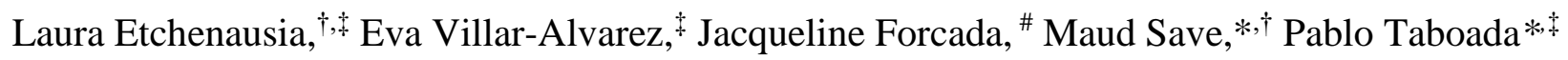

$\dagger$ CNRS, University Pau \& Pays Adour, E2S UPPA, Institut des Sciences Analytiques et de Physico-Chimie pour l'Environnement et les Matériaux, IPREM, UMR5254, 64000, PAU, France † Condensed Matter Physics Department, Faculty of Physics, 15782 Campus Sur, Universidad de Santiago de Compostela, Santiago de Compostela, Spain.

\# Bionanoparticles Group, Department of Applied Chemistry, University of the Basque Country UPV/EHU, Donostia-San Sebastián, Spain.

Corresponding authors:

Prof. Pablo Taboada; email: pablo.taboada@usc.es; Phone: +34 881814111

Dr. Maud Save; email: maud.save@univ-pau.fr; phone : +33 540175014

\section{Abstract}

The present work investigates the potentiality of poly( $N$-vinyl caprolactam) (PVCL)-based thermoresponsive microgels decorated with cationic polymer brushes as drug delivery carriers. The effect of physico-chemical features of the colloids on cell viability response have to be carefully investigated to establish the range of suitable hydrodynamic diameters, crosslinking densities, lengths and ratios of the cationic polyelectrolyte shell which allow their efficient and effective use for cargo loading, transport and delivery. The colloidal stability of all cationic thermoresponsive microgels is maintained over several days of incubation at $37^{\circ} \mathrm{C}$ in biological mimicking medium (Dulbecco's Modified Eagle's Medium supplemented with fetal bovine serum). The thin cationic 
polymer shell covalently anchored does not hinder the all range of microgels to be biocompatible while the higher cytotoxicity of the doxorubicin-loaded microgels on HeLa cells proves their antitumor activity. The core-shell PVCL drug delivery nanocarriers allow a sustained release of doxorubicin with a slightly higher viability of HeLa cells incubated in the presence of DOXOloaded microgels compared to the free DOXO. The nature of the endocytosis pathway is investigated through a quantification of the extent of the cellular survival rate in the presence of various cellular uptake inhibitors. A clathrin-dependent internalization was observed.

Keywords: Cationic thermoresponsive microgels, in-vitro drug delivery, cell internalization pathway

\section{Introduction}

In the field of human disease therapies and, more specifically, cancer therapies, pharmaceutical molecules (drugs, proteins, nucleic acids) are usually administered intravenously, which generally leads to short residence time, limited targeting and penetration of tumor tissues, toxic reactions in healthy tissues, and limitations to reach optimal effective doses.[1] Therefore, a major challenge consists in designing drug carriers in order to improve the safety and efficacy of therapeutic agents. Drug delivery systems (DDS) are ideally suitable to protect the active compounds from the surrounding environment (preventing their early degradation), consequently increasing their in-vivo circulation to deliver the drug concentration required for an optimal therapeutic efficacy, without damaging the healthy cells or tissues.[2, 3] Thus, a robust delivery platform needs to satisfy some requirements. First of all, the size of the carrier is an important parameter to consider since it plays a key role in its degradation, its cellular uptake and its blood circulation life, among other functional aspects.[4-6] For instance, the size of the vehicle should be 
large enough to prevent rapid leakage in blood capillaries but small enough to escape the capture of macrophages in the reticuloendothelial system (RES), i.e., sizes ranging from a few tenths to a few hundreds of nanometers. Biocompatibility and non-toxicity are also imperative criteria for a suitable delivery system.[7, 8] Among the different systems that have been envisaged as nanocarriers for therapeutics, submicronic polymeric nanogels or microgels are very promising candidates due to their versatile properties such as easy production and functionalization, large surface area, porous network, high loading capacity and potential responsiveness to environmental factors of some varieties, which allows a triggered release of the therapeutics.[9-17] Thermoresponsive nano/microgels that undergo a volume phase transition in aqueous media upon subtle temperature changes have attracted interest as DDS within the last past years in order to control the sustained drug release and uptake performance when collapsing.[1, 2, 18-23] Among the different classes of thermoresponsive polymers, $\operatorname{poly}(N$-vinylcaprolactam) (PVCL) has proven to be very attractive to design nano/microgels for biomedical applications thanks to its biocompatibility and lower critical solution temperature in the range of the physiological temperature.[24-29]

Polymeric cationic vehicles are of special interest due to their ability to interact with the negatively charged cell membrane facilitating their cellular uptake.[2] Moreover, they can strongly interact with negatively charged relevant biological molecules such as DNA and siRNA (whose charge and size make them non-permeable to cell membranes) facilitating their delivery into cells.[30-34] Cationic thermoresponsive microgels have also been conjugated with anionic dyes for bio-imaging applications.[35] The present work aims to investigate the in-vitro bioactivity of the original core-shell microgels as drug delivery nanocarriers to combine the advantage of the highly accessible covalently anchored cationic outer shell with the ones of a crosslinked thermoresponsive core with encapsulation capacity. We have previously reported the synthesis in 
aqueous dispersed media of this type of microgels using a strategy to covalently anchor the cationic polyelectrolyte exhibiting permanent cationic charges with the PVCL chains forming the crosslinked microgels.[36] The potential use of this cationic PVCL-based microgels for biomedical applications is conditioned by their stability in different biological mimicking media and their invitro cytotoxicity towards different cell lines. These properties are studied in the present work for a series of microgels with various structural features (crosslinking degree, length and ratio of the cationic polyelectrolyte and microgel swelling ratio) before to investigate the cellular uptake of the cationic PVCL-based microgels by confocal microscopy and more precisely their internalization pathway into HeLa cells by means of inhibition uptake experiments (Scheme 1). To complete the study, a model anticancer drug (doxorubicin, DOXO) is loaded into the PVCL-based microgels in order to test their potential use as chemotherapeutic drug delivery systems for cancer treatment. Attention is thus paid to the drug release profiles of selected microgels and to the cytotoxicity of the DOXO-loaded microgels on HeLa and RAW cell lines.

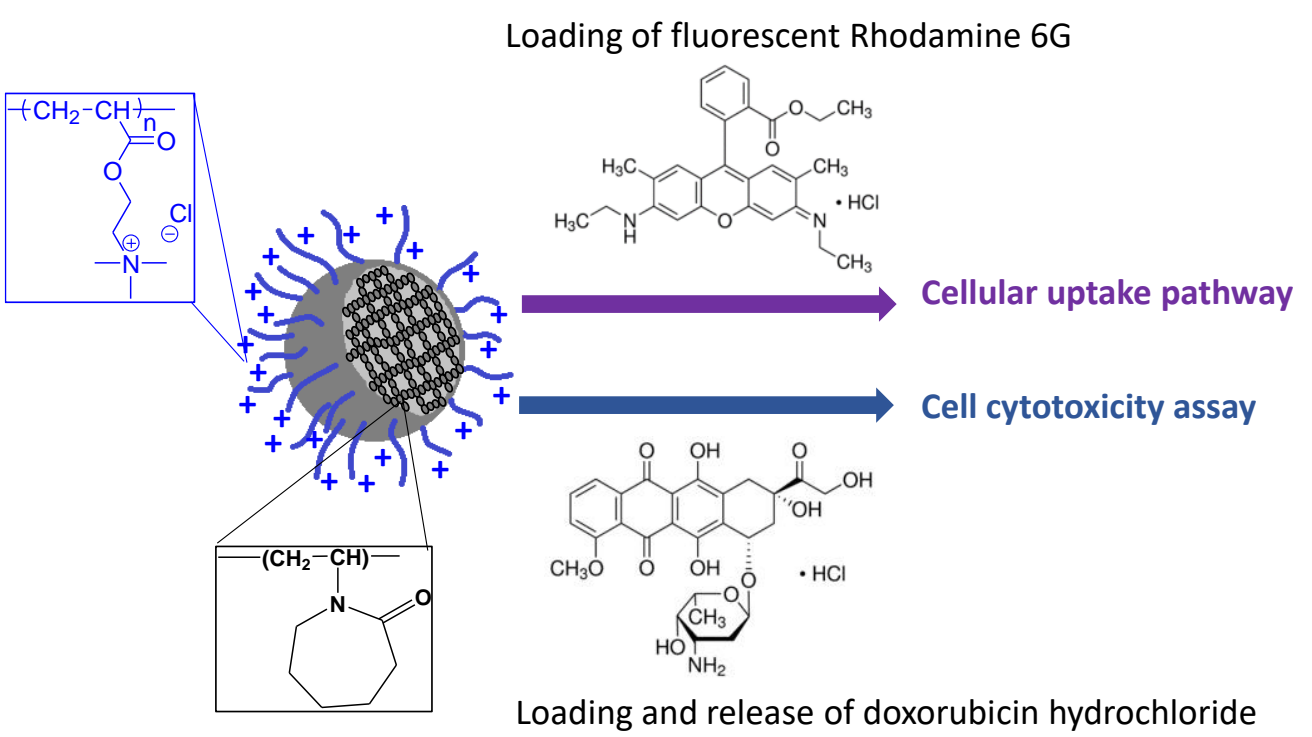

Scheme 1. Structures of thermoresponsive PVCL-based microgels decorated with covalently grafted cationic polyelectrolyte brushes and of loaded Rhodamine 6G, doxorubicin hydrochloride. 


\section{Materials and Methods}

\section{Materials}

Reagents and cell lines

$N$-Vinylcaprolactam (VCL, Sigma Aldrich, 98\%), ethylene glycol dimethacrylate (EGDMA, Sigma Aldrich, 98\%), potassium persulfate (KPS, Sigma Aldrich, 99\%), sodium bicarbonate $\left(\mathrm{NaHCO}_{3}\right.$, Sigma-Aldrich, 99.7\%), 2,2'-Azobis[2-(2-imidazolin-2-yl)propane] dihydrochloride (ADIBA or VA-044, Wako, 99\%), 4,4'-azobis(4-cyano)pentanoic acid (ACPA, Fluka, $98 \%$ ), cetyltrimethylammonium $\quad$ bromide $\quad$ (CTAB, Sigma Aldrich, 99\%), tris(hydroxymethyl)aminomethane hydrochloride (TRIZMA, Sigma Aldrich, 99\%) and 1,3,5trioxane (Sigma Aldrich, 99\%) were used as received. [2-(acryloyloxy)ethyl]trimethylammonium chloride solution (AETAC, Arkema, 98 wt-\% in water) was passed under inhibitors remover (Sigma Aldrich, $0.1 \mathrm{~g}$ in order to purify $50 \mathrm{~mL}$ of monomer) before use. Double deionized (DDI) water was used for the microgel synthesis. Dulbecco's Modified Eagle's Medium (DMEM), Dulbecco's Modified Eagle's Medium/Nutrient Mixture F-12 Ham (DMEM/F-12), sodium pyruvate solution $(100 \mathrm{mM})$ and non-essential amino acid solution were purchased from Life Sciences. Fetal Bovine Serum (FBS), Cell Counting Kit-8 (CCK-8), chlorpromazine hydrochloride (98\%), phosphate buffered saline (PBS, 10× concentrate, BioPerformance Certified, suitable for cell culture, $\mathrm{NaCl} 0.137 \mathrm{M}, \mathrm{KCl} 0.0027 \mathrm{M}, \mathrm{Na}_{2} \mathrm{HPO}_{4} 0.01 \mathrm{M}, \mathrm{KH}_{2} \mathrm{PO}_{4} 0.0018 \mathrm{M}$ ), triton X-100, doxorubicin hydrochloride (98-102\%, Scheme 1) and fluorescent dye rhodamine 6G (R6G, red, 99\%, Scheme 1) were obtained from Sigma Aldrich. Trypsin-EDTA (0.25\%), phenol red and penicillin-streptomycin $(10,000 \mathrm{U} / \mathrm{mL})$ were supplied by Gibco, ThermoFisher Scientific. D (+)Sucrose (99\%, RNAse and DNAse free) was obtained from Acros Organics. Paraformaldehyde 
was acquired from Fisher Scientific. 4'-6-diamidino-2-phenylindole dihydrochloride, ProLong Gold antifade (DAPI, blue) was supplied by Invitrogen.

Cervical cancer HeLa cell line was obtained from Cell Biolabs and RAW 264.7 cell line from ATCC, Manassas, Virginia.

Synthesis of PVCL-based microgels.

PVCL-based microgels were synthesized following the previously reported [36] by batch emulsion copolymerization of $N$-vinylcaprolactam (VCL) monomer and ethylene glycol dimethacrylate (EGDMA) crosslinker stabilized by a reactive poly([2-(acryloyloxy)ethyl]trimethylammonium chloride) P(AETAC-X) which was synthesized by controlled radical polymerization (see details of microgel synthesis and characterization in Electronic Supplementary Materials, Table S1 and Table S2). The codes of the microgels displays the different experimental parameters used for their synthesis, like for instance $\mathrm{SC}_{1-\mathrm{PX}_{76}}$ 4-E4. SC represents the initial solids content, the number following indicates the wt- $\%$ of VCL based on water, $\mathrm{PX}_{\mathrm{n}}$ is the reactive cationic polymeric stabilizer with $n$ the degree of polymerization, the number following indicates the wt- $\%$ of stabilizer based on VCL and E corresponds to EGDMA crosslinker, the number following indicates the wt- $\%$ of EGDMA based on VCL.

\section{Methods}

Cell culture. The cervical HeLa cancer cell line was grown in a medium composed of DMEM, 1 $\mathrm{v} / \mathrm{v} \%$ penicillin-streptomycin, $1 \mathrm{v} / \mathrm{v} \%$ sodium pyruvate, $1 \mathrm{v} / \mathrm{v} \%$ amino acid and $10 \mathrm{v} / \mathrm{v} \%$ of FBS. The same medium was used for the growth of RAW cell line but DMEM/F-12 was used instead of DMEM. Both cell lines were grown in an $5 \% \mathrm{CO}_{2}-95 \%$ air atmosphere at $37^{\circ} \mathrm{C}$. After attaining $80-$ 
$90 \%$ confluence, cells were harvested using trypsin (0.25\%)-EDTA. Cell count was conducted using an automated cell counter (Multisizer 3 Beckman Coulter Cell Counter).

Colloidal stability of bare PVCL-based microgels in biological mimicking media. The colloidal stability of bare PVCL-based microgels was tested at $37^{\circ} \mathrm{C}$ under slow stirring for 13 days, by dilution of the samples $\left(0.05 \mathrm{mg} \cdot \mathrm{mL}^{-1}\right)$ in different biological mimicking media: cell culture medium (DMEM) supplemented with 10\% FBS (pH 8.4), PBS (pH 7.4) and PBS supplemented with $10 \%$ FBS (pH 7.4). Stability of the microgels was also assessed in water, following the same procedure. The evolution of the hydrodynamic diameter $\left(D_{\mathrm{h}}\right)$ of the microgels along the incubation time was monitored by dynamic light scattering (DLS) using a Zetasizer Nano ZS instrument (Malvern Instruments). Samples were allowed to equilibrate at $37^{\circ} \mathrm{C}$ for $2 \mathrm{~min}$ before analysis.

Doxorubicin loading and release. Microgel dispersions at $2 \mathrm{mg} \cdot \mathrm{mL}^{-1}$ in water and a DOXO solution at $1 \mathrm{mg} \cdot \mathrm{mL}^{-1}$ in water were prepared and heated to $37^{\circ} \mathrm{C}$ using an oil-bath. Then, $500 \mu \mathrm{L}$ of the microgel dispersion and $100 \mu \mathrm{L}$ of the DOXO solution were mixed together at $37^{\circ} \mathrm{C}$ for 5 min and then the mixture was kept at $4^{\circ} \mathrm{C}$ for $24 \mathrm{~h}$. Subsequently, microgel particles were separated from the aqueous solution containing free DOXO through centrifugation for $1 \mathrm{~h}$ at $15000 \mathrm{rpm}$ and $15^{\circ} \mathrm{C}$. Supernatants were collected, kept away from light and analyzed by UV-Vis spectroscopy at $488 \mathrm{~nm}$ (Cary 50 spectrophotometer, Agilent Technologies, Germany) in order to determine the amount of encapsulated DOXO. A previously obtained calibration curve for DOXO in water was used $\left(\mathrm{Abs}_{\text {DOXO, }} 488 \mathrm{~nm}=19.691 \times[\mathrm{DOXO}]+0.027\right.$, with $[\mathrm{DOXO}]:$ DOXO concentration in $\mathrm{mg} \cdot \mathrm{mL}^{-}$ ${ }^{1}$ ). Drug loading (D.L.) and entrapment efficiency (E.E.) were calculated using the following equations: 
D.L. $\%=\frac{\text { weight of the drug in micràgel dispersion }(\mathrm{mg})}{\text { weight of polymer }+ \text { weight of the drug in microgel dispersion }(\mathrm{mg})} \times 100$ Equation 1

E.E. \% $=\frac{\text { weight of the drug in nanogel dispersion }(\mathrm{mg})}{\text { weight of feeding drug }(\mathrm{mg})} \times 100$ Equation 2

The in-vitro release of DOXO from selected microgels $\left(1 \mathrm{mg} \cdot \mathrm{mL}^{-1}\right)$ was assessed by a dialysis method. Release of free DOXO was also performed as a control in order to take into consideration the simple diffusion of the free drug through the semipermeable membrane. DOXO-loaded SC1-

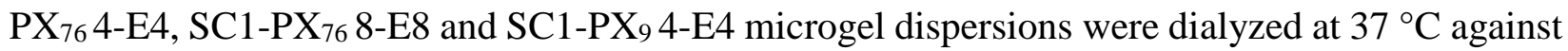
two different serum-containing (10\% (v/v) FBS) buffer solutions: sodium acetate/acetic acid (SA) buffer solution ( $\mathrm{pH}$ 5.5) and phosphate buffer saline (PBS) solution ( $\mathrm{pH} 7.4)$. The DOXO release concentration in the release medium was determined spectrophotometrically at $488 \mathrm{~nm}$. All experiments were performed in triplicate.

In vitro cell cytotoxicity assays. Cytotoxicity of bare PVCL-based microgels was evaluated on cervical HeLa and RAW 264.7 cell lines utilizing the Cell Counting Kit-8 (CCK-8) cytotoxicity assay.[37, 38] Both cell lines were seeded in 96 well-plates at a density of 5000 cells per well in $100 \mu \mathrm{L}$ of growth medium (DMEM for HeLa cells and DMEM/F-12 for RAW cells, respectively) and allowed to grow for $24 \mathrm{~h}$ at $37^{\circ} \mathrm{C}$. Then, the medium was removed and cells were exposed to $100 \mu \mathrm{L}$ of various concentrations of cationic poly( $N$-vinylcaprolactam)-based microgels (Test 1 : $[$ Microgel $]=0.005 ; 0.05 ; 0.1 ; 0.25 ; 0.5$ and $1 \mathrm{mg} \cdot \mathrm{mL}^{-1}-$ Test $2:[$ Microgel $]=0.5 ; 1 ; 2 ; 3.5 ; 5$ and $10 \mathrm{mg} \cdot \mathrm{mL}^{-1}$ ) dispersed in growing media for further incubation at $37^{\circ} \mathrm{C}$ in a $5 \% \mathrm{CO}_{2}$ atmosphere for 24 and $48 \mathrm{~h}$. After incubation, 10\% CCK-8 solution per well was added and incubated for $1 \mathrm{~h}$ for RAW cell line and 90 min for HeLa cell line. The absorbance of viable cells was subsequently 
measured at $450 \mathrm{~nm}$ using an UV-Vis microplate absorbance reader (Microplate Manager 5.0, BioRad Laboratories, USA). The non-treated cells served as a 100\% cell viability control (blank). Survival percentage or cell viability was calculated as follows:

$\%$ Cell viability $=\frac{A b s_{\text {treated cells }}-\text { Abs microgel }}{A b s_{\text {untreated cells }}} \times 100$ Equation 3

where $A b s_{\text {treated cells }}$ is the absorbance at $450 \mathrm{~nm}$ of cells incubated in the presence of microgels, and $A b s_{\text {untreated cells }}$ is the absorbance at $450 \mathrm{~nm}$ of control cells in the absence of microgel particles. The absorbance of microgels at $450 \mathrm{~nm}$ was substracted to the absorbance of treated cells for each microgel concentration.

The same procedure was followed to study the DOXO-loaded microgel cytotoxicity on RAW and HeLa cell lines after $24 \mathrm{~h}$ of incubation. Cells were exposed to various concentrations of DOXOloaded microgels: [DOXO-loaded microgel] $=2 ; 1 ; 0.5 ; 0.25$ and $0.1 \mathrm{mg} \cdot \mathrm{mL}^{-1}$.

For each microgel, the concentration of DOXO (Table S4) was calculated according to equation 4 by using the microgel weight concentrations and the entrapment efficiency (see Table S2).

$$
[D O X O](\mu M)=\left(\frac{[\text { Microgel }] \times E . E \times 10^{-3}}{M_{D O X O}}\right) \times 10^{6} \text { Equation } 4
$$

where E.E is the entrapment efficiency (Equation 2) and $M_{\text {Doxo }}$ is the DOXO molar mass ( $M_{\text {DOXO }}$ $\left.=579.98 \mathrm{~g} \cdot \mathrm{mol}^{-1}\right)$.

Cellular uptake by fluorescence microscopy. Prior to the cellular uptake experiments, the microgels were labeled with rhodamine $6 \mathrm{G}\left(\lambda_{\mathrm{exc}}=530 \mathrm{~nm}\right)$ according to the following procedure. Microgel dispersions at $1 \mathrm{mg} \cdot \mathrm{mL}^{-1}$ in water and a solution of rhodamine $6 \mathrm{G}$ at $10 \mathrm{mg} \cdot \mathrm{mL}^{-1}$ also in water were prepared and heated to $37^{\circ} \mathrm{C}$ in an oil-bath. Then, $1 \mathrm{~mL}$ of the microgel dispersion and $400 \mu \mathrm{L}$ of 
the rhodamine solution were mixed together at $37^{\circ} \mathrm{C}$ and the mixture was kept at $4{ }^{\circ} \mathrm{C}$ for $24 \mathrm{~h}$. Subsequently, microgel particles were separated from the aqueous solution containing free R6G through four successive centrifugations for $1 \mathrm{~h}$ at $15000 \mathrm{rpm}$ and $15^{\circ} \mathrm{C}$. After centrifugations, the resulting pellet was re-dispersed in cell culture medium at the desired concentration. As a concentrated solution of $\mathrm{R} 6 \mathrm{G}$ in water $\left(10 \mathrm{mg} \cdot \mathrm{mL}^{-1}\right)$ was used, several centrifugations were required to separate the R6G-loaded microgels from free R6G. The cellular uptake of R6G-loaded microgels was followed by confocal fluorescence microscopy. HeLa cells were seeded on poly-(Llysine $)$ coated glass coverslips $(12 \times 12 \mathrm{~mm})$ placed inside 6 well-plates $\left(15 \times 10^{4}\right.$ cells/well with $3 \mathrm{~mL}$ of DMEM), and allowed to grow for $24 \mathrm{~h}$ at standard culture conditions. The growth medium was then removed, and $500 \mu \mathrm{L}$ of a dispersion of R6G-loaded microgels in DMEM at a concentration of $0.5 \mathrm{mg} \cdot \mathrm{mL}^{-1}$ and $2.5 \mathrm{~mL}$ in DMEM were added to each well. Cells were then incubated for 3 and $24 \mathrm{~h}$, respectively. For energy-dependent uptake experiments at $4^{\circ} \mathrm{C}$, cells were pre-incubated at $4^{\circ} \mathrm{C}$ with serum-free DMEM for $1 \mathrm{~h}$, followed by incubation with $500 \mu \mathrm{L}$ of R6Gloaded microgel dispersions in serum-free DMEM (at a concentration of $0.5 \mathrm{mg} \cdot \mathrm{mL}^{-1}$ ) at the same temperature for $3 \mathrm{~h}$. To inhibit a specific uptake mechanism of microgels into cells, these were preincubated with the following inhibitors individually for $1 \mathrm{~h}$ at $37^{\circ} \mathrm{C}: 400 \mathrm{mM}$ hypertonic sucrose, $30 \mu \mathrm{M}$ chlorpromazine, $30 \mu \mathrm{M}$ cytochalasin and $30 \mu \mathrm{M}$ nystatin, respectively. After the preincubation time, the inhibitor solutions were removed and the freshly prepared R6G-loaded microgel dispersed (at a concentration of $0.5 \mathrm{mg} \cdot \mathrm{mL}^{-1}$ ) in media containing inhibitor at the same concentrations were added and further incubated for $3 \mathrm{~h}$ at $37^{\circ} \mathrm{C}$. In this study, cells incubated for $3 \mathrm{~h}$ at $37^{\circ} \mathrm{C}$ in the presence of R6G-loaded microgel and in the absence of inhibitor were used as controls. For all the experiments described above, after the desired incubation times cell culture media were removed and the microgel-containing cells were washed three times with PBS $(\mathrm{pH}$ 7.4), fixed for 10 minutes with a solution of paraformaldehyde at $4 \mathrm{w} / \mathrm{v} \%$ in PBS, washed with 
PBS, treated for 10 minutes with a solution of Triton X-100 (permeabilizer) at $0.25(\mathrm{w} / \mathrm{v}) \%$ in PBS and, finally, washed again with PBS. Coverslips were mounted on glass slides and cell nuclei were stained with 4'-6-diamidino-2-phenylindole dihydrochloride (DAPI, blue). The samples were cured at $-20^{\circ} \mathrm{C}$ for $24 \mathrm{~h}$ before being visualized with an $63 \mathrm{X}$ oil-immersion objective using an inverted wide field fluorescence microscope (Leica DMI6000B, Leica Microsystems, Germany) with the blue channel for DAPI-stained cell nuclei $\left(\lambda_{\mathrm{exc}}=355 \mathrm{~nm}\right)$, the red channel for R6G $\left(\lambda_{\mathrm{exc}}=\right.$ $590 \mathrm{~nm}$ ) and the transmitted light channel in differential interference contrast (DIC) mode.

\section{Results and discussion}

\section{Colloidal stability of bare cationic PVCL microgels.}

The stability in biological mimicking media of a series of poly( $N$-vinylcaprolactam) (PVCL) microgels surrounded by covalently anchored poly[2-(acryloyloxy)ethyl]trimethylammonium chloride (P(AETAC-X) cationic polymer shell is investigated for various colloids (Scheme 1). All these microgels dispersed in water will be named "bare microgels" in the following work. Their diameters at $37^{\circ} \mathrm{C}$ range between $100-200 \mathrm{~nm}$ (Table S2). Different physico-chemical parameters of the series of SC-PX-E microgels (Scheme 1) are controlled by their synthesis [36]: 1) the length of the cationic brushes, 2) the ratio of the cationic P(AETAC) versus PVCL, 3) the crosslinking density which can be tuned by either the initial crosslinker amount versus VCL or by the initial solids content of emulsion polymerization that influence the mesh size of the network.[36] For biomedical applications, the stability of the particles in biological media is of high importance since their particle size can affect their biodistribution and cell internalization and fate.[4, 39] The hydrodynamic diameters of the bare microgels were monitored for 13 days of incubation at $37^{\circ} \mathrm{C}$ to investigate their colloidal stability (Figure $\mathbf{1}$ and Figure S1 in Supplementary materials). 
Microgels were dispersed (at $0.05 \mathrm{mg} \cdot \mathrm{mL}^{-1}$ ) either in water ( $\mathrm{pH}$ 6.5) or in three different biological mimicking media: $i$ ) bare PBS (pH 7.4), ii) PBS supplemented with 10\% FBS (pH 7.4), iii) cell culture medium (DMEM, pH 8.4) supplemented with 10\% FBS. PBS and PBS supplemented with FBS mimicks somehow the physiological serum conditions of increasing complexity whereas DMEM supplemented with FBS corresponds to the cell culture medium used for the in-vitro studies (cytotoxicity and cell internalization).
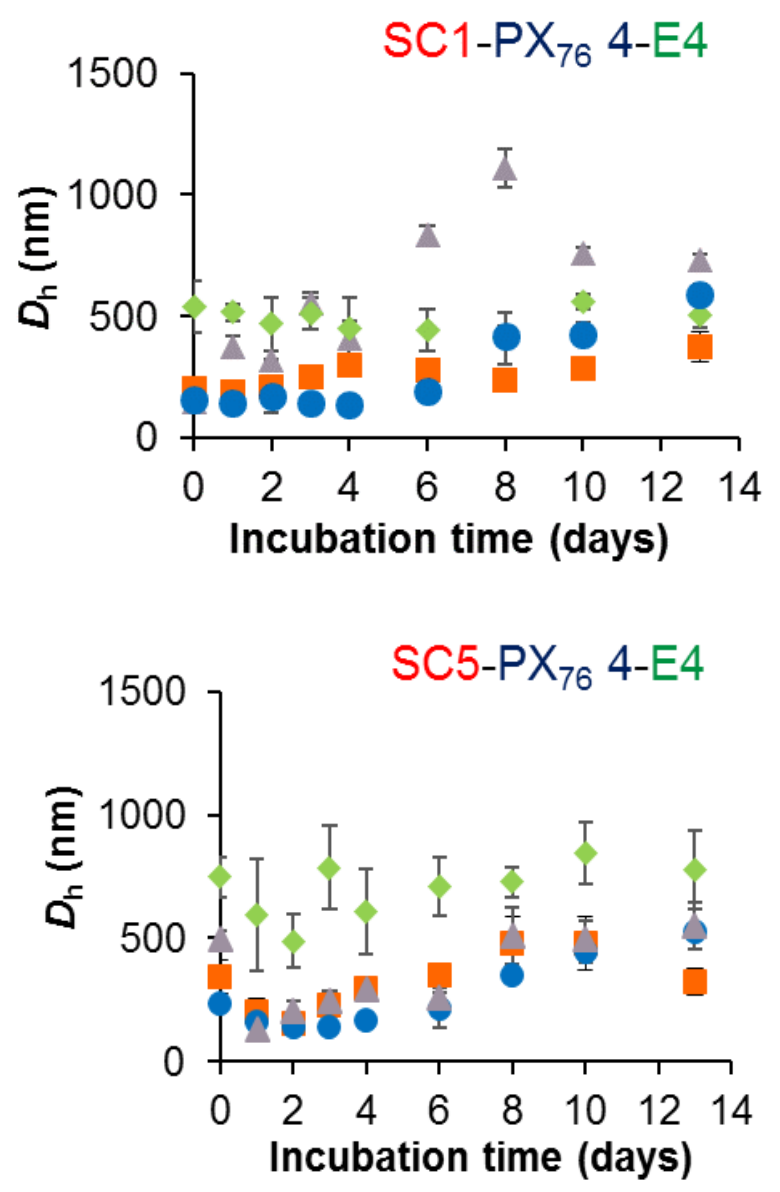


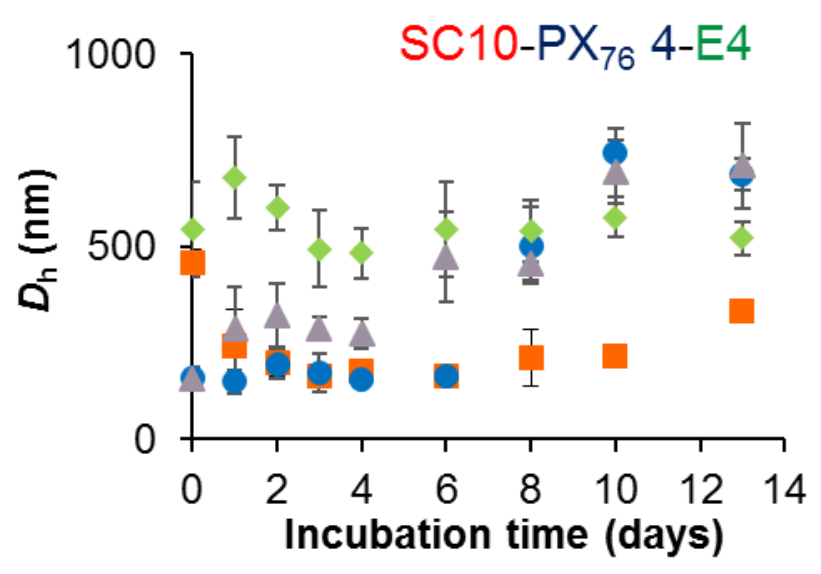

Figure 1. Temporal evolution of the hydrodynamic diameter of bare selected microgels at $37^{\circ} \mathrm{C}$, in: $(\boldsymbol{\square})$ water, $(\boldsymbol{\bullet})$ cell culture medium DMEM + 10\% FBS, $(\bullet) \mathrm{PBS}$ and $(\boldsymbol{\Delta}) \mathrm{PBS}+10 \% \mathrm{FBS}$.

In water, all microgels remained stable since their hydrodynamic diameters were almost constant during the whole incubation $\left(13\right.$ days at $\left.37^{\circ} \mathrm{C}\right)$. In contrast, an obvious increase of the microgel hydrodynamic diameter at the beginning of incubation was systematically observed in PBS buffer revealing a certain lack of microgel stability. Since the ionic strength of PBS buffer is around 150 $\mathrm{mM}$, the increase of the microgel hydrodynamic diameters could be explained by the formation of aggregates due to the ionic screening of the particle electrical charges. Indeed, the reduction of the particle surface charges might lead to the microgel destabilization by decreasing the electrostatic repulsions between particles. The salt effect on microgel stability was also studied for SC5-PX 76 4-E4 microgel in aqueous solution at different concentrations of $\mathrm{KBr}$ ranging from $10 \mathrm{mM}$ to 100 mM. An increase of the microgel hydrodynamic diameters was observed above the microgel VPTT, suggesting the formation of aggregates (Figure S2 in Supplementary materials). Such colloidal instability and aggregation of positively charged carriers in fluids at high salt concentration is a well-known process, being one of the main drawbacks for their use, for example, as gene delivery systems.[32, 40] It should be noted that the aggregation of the cationic PVCL- 
based microgels is observed at their collapsed state $\left(\mathrm{T}>30^{\circ} \mathrm{C}\right)$ but a similar value of $D_{\mathrm{h}}$ was measured at low temperature (swollen state) whatever the salt concentration (Figure S2 in Supplementary materials). The screened cationic polyelectrolyte does not provide then a sufficient protective layer against the hydrophobic interaction of the collapsed microgels.

In PBS supplemented with FBS, microgels are more stable than in the presence of pure PBS, at least at short incubation times (< 6 days, see for example, SC5-PX, 4-E4, SC1-PX 9 4-E4; SC1$\mathrm{PX}_{16}$ 4-E4 and SC1-PX 76 4-E4). In DMEM supplemented with FBS, the hydrodynamic diameters of SC1-PX 76 8-E4, SC1-PX 16 12-E4, SC1-PX 76 4-E4, SC5-PX 76 4-E4 and SC10-PX 76 4-E4 microgels did not suffer any substantial changes for 6 days of incubation; interestingly, SC1-PX 9 4-E4, SC5-PX 9 4-E4, SC5-PX 76 8-E4, SC1-PX 76 8-E4 and SC1-PX 16 4-E4 microgels do not undergo significant size change along the whole 13 days incubation period.

The origin of microgel destabilization in FBS supplemented media (either PBS or DMEM) could be the formation of aggregates of microgel particles as a consequence of the absorption of proteins onto the particle surfaces and the subsequent exchange kinetics between low affinity-highly abundant serum proteins and high affinity-less abundant ones. Indeed, in FBS the main constitutive plasma protein is bovine serum albumin (BSA), which is negatively charged at $\mathrm{pH} 7.4$ (isoelectric point of BSA = 4.7).[41] Since the microgel particles used in this work are positively charged, BSA could adsorb firstly and quick onto microgel surfaces by electrostatic attraction, increasing their size.[42] Moreover, the reduction of the microgel surface charge by adsorption of the protein molecules could lead to the formation of aggregates of microgel particles.[43, 44] In addition to the adsorption of BSA through electrostatic attractions, hydrophobic interactions should also be considered in this process provided that it has been previously demonstrated that for $\operatorname{poly}(N$ isopropylacrylamide)-based microgels protein adsorption was enhanced above the microgel VPTT as a result of the latter type of interactions between the protein and the hydrophobic collapsed 
microgel.[45, 46] The higher stability of the microgels in FBS supplemented media (either PBS or DMEM) than in serum free one (PBS) might arise from salt aggregating effects being initially screened by the formation of a protein corona at the microgel surfaces. This process known as opsonization enables protein adsorption and recognition of foreign elements by macrophages and the reticulo-endothelial system (RES), allowing their clearance from the body.[42] Upon incubation, this protein corona might be destabilized through exchange dynamics with smaller ions or even other less abundant proteins possessing larger affinities, leading to a reduction of the microgel surface charge and, thus, to the particle aggregation/clustering.

On the other hand, it should be noted that there are not very clear specific trends between the colloidal stability of microgels and their structural features, but some qualitative observations can be made. For example, an increasingly amount of solids content in the microgel formulation seems to alter the colloidal stability, particularly in media supplemented with FBS at relatively long incubation times as observed when comparing microgels SC1-PX 76 4-E4, SC5-PX 76 4-E4 and SC10-PX 76 4-E4 (Figure 1). Also, microgels bearing larger ratios of the polycation stabilizer undergo larger increments in their hydrodynamic sizes at 6-8 days of incubation pointing to a certain progressive loss of their colloidal stability, especially noted in the presence of FBSsupplemented media as observed when compared SC1-PX 76 4-E4 and SC1-PX 76 8-E4 or for SC1$\mathrm{PX}_{16} 4-\mathrm{E} 4$ and SC1-PX 16 12-E4 microgels (see Figure 1 and Figure S1). Conversely, no trends could be elucidated neither in terms of the stabilizer length nor the crosslinking ratio.

In summary, the incubation time should be carefully considered for an implementation of the cationic PVCL microgels in blood serum conditions. In serum supplemented media, the time along which these microgels remain stable is much longer than that required for routinely in-vitro studies (maximum 72h)[44, 47-49] or for potential in-vivo applications. In the present work, for experiments of microgel in-vitro cell cytotoxicity assays or internalization experiments microgels 
were used after dispersion in DMEM cell culture medium supplemented with FBS for a maximum of two days. Since in this medium the microgel hydrodynamic diameters remained constant for up to 6 days, microgel destabilization should not play a significant effect on the obtained results.

\section{In vitro cell cytotoxicity assays of bare PVCL-based microgels}

The cytotoxicity of bare PVCL-based microgels at different concentrations (from 0.005 to 10

mg.mL ${ }^{-1}$ ) was assessed on HeLa and RAW cell lines after $24 \mathrm{~h}$ and $48 \mathrm{~h}$ of incubation, using the Cell Counting Kit-8 (CCK-8) cytotoxicity assay. The cell viabilities for the different microgels (expressed as cell viability percentage) are reported as a function of the microgel concentration for HeLa and RAW cell lines at the different incubation times (Figure 2 and Figure $\mathbf{S 3}$ in Supplementary materials).

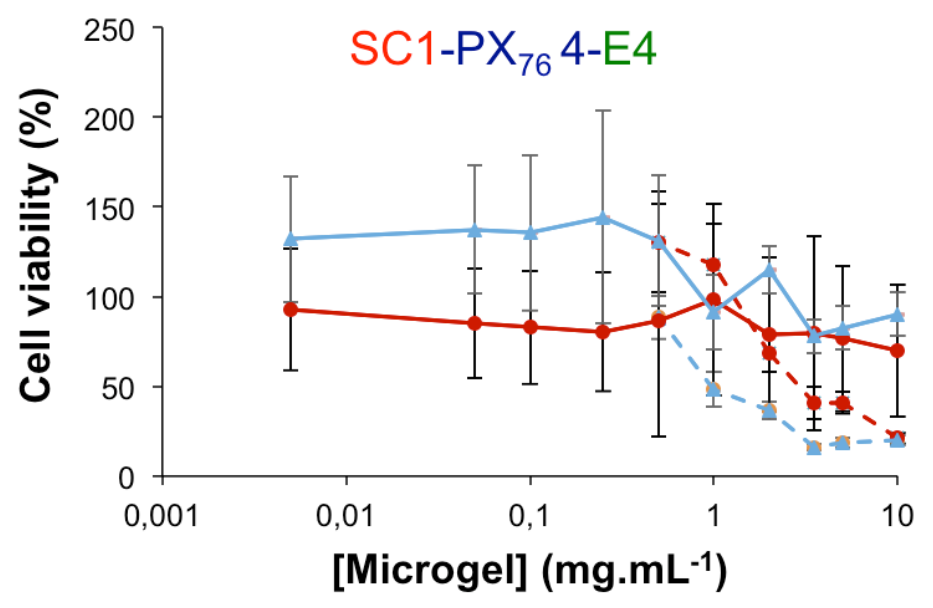



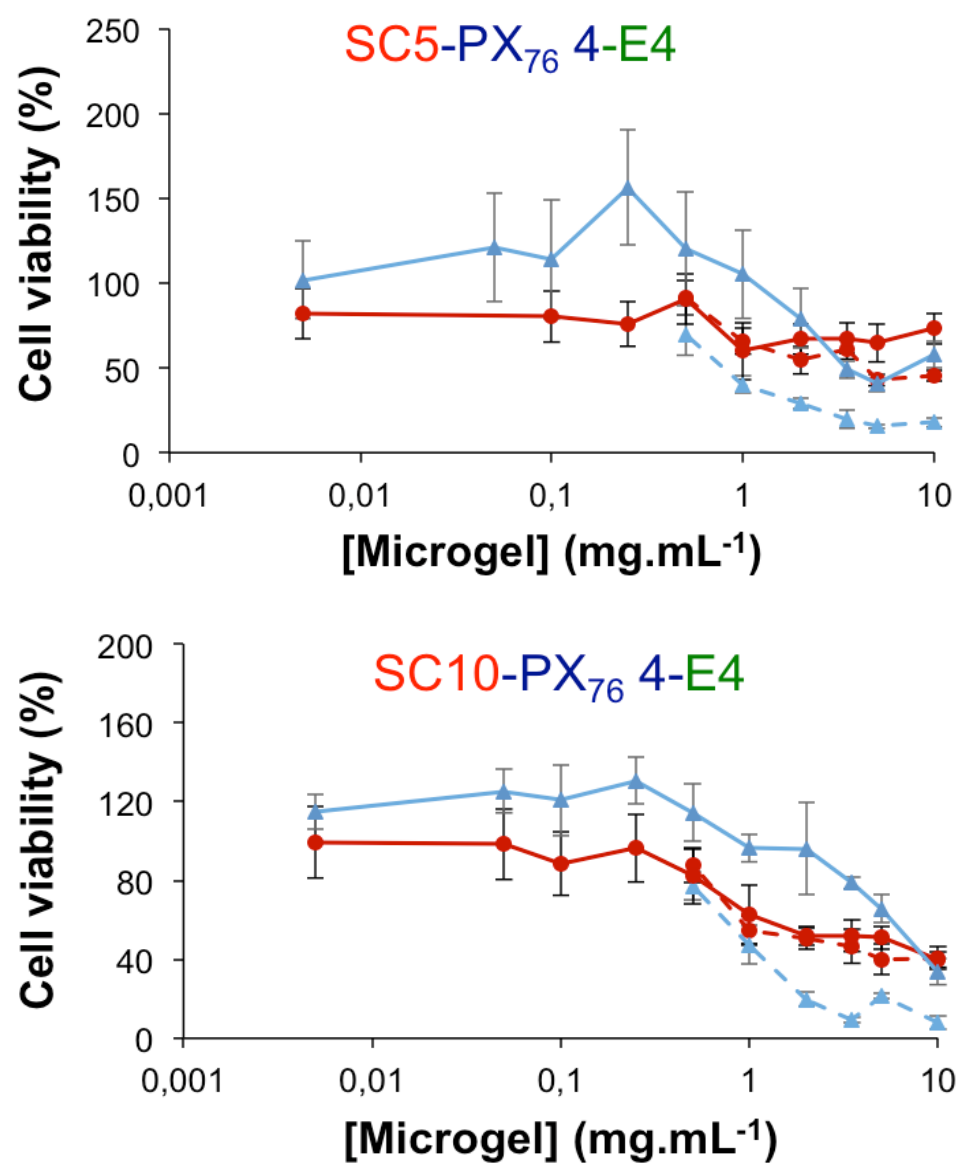

Figure 2. Cell viability of: (O) HeLa and ( $\mathbf{\Delta}) \mathrm{RAW}$ cell lines after incubation at $37^{\circ} \mathrm{C}$ with different concentrations of microgels. Full line: 24 h of incubation; Dotted line: $48 \mathrm{~h}$ of incubation.

The series of microgels achieve significant cell viabilities in both types of cells with a dosedependent behavior. A similar dose-dependent cytotoxicity was also observed for other PVCLbased nano/microgels [44] or PVCL-based copolymers.[50, 51] After $24 \mathrm{~h}$ of incubation, the growth inhibition observed in both HeLa and RAW cells lines is almost negligible for microgel concentrations up to $1 \mathrm{mg} \cdot \mathrm{mL}^{-1}$, and even for macrophages some additional proliferation compared to the control cells is noted. Moreover, cell viabilities for both cell lines were above $70 \%$ for microgel concentrations between 0.005 and $2 \mathrm{mg} \cdot \mathrm{mL}^{-1}$ indicating that almost all of the microgels have a good biocompatibility.[44, 52] After $48 \mathrm{~h}$ of incubation, a slight additional reduction of cell 
viability for microgels incubated with HeLa cells occurs, and this decrease is larger in the case of RAW macrophages. The observed larger cytotoxicity of microgels at concentrations $>2 \mathrm{mg} \cdot \mathrm{mL}^{-1}$ and particularly, at the largest one $10 \mathrm{mg} \mathrm{mL}^{-1}$, can be originated from an excess of microgel particles producing a damage to cells leading to their death.[53] Indeed, this overpopulation might involve membrane-cell disruption due to the high amount of nanoparticles in the medium interacting with the cells and/or large amounts of particles being internalized into cells, hence disrupting the cell cytoplasm (for example, by the formation of a high number of vacuoles), altering the cell metabolic activity and, thus, activating the programed cell death cascade pathways. In this regard, it is worth mentioning that cationic particles are usually more toxic to cells than neutral or negatively charged ones due to the stronger electrostatic interactions with the cell surface, hence, causing larger cellular membrane disruption effects (alteration of the anionic lipidic and protein domains). Herein, for microgel concentrations above $2 \mathrm{mg} \cdot \mathrm{mL}^{-1}$ the cell viability is also lower for RAW cells than for HeLa ones, particularly after $48 \mathrm{~h}$ of incubation. This result was consistent with the fact that RAW macrophages uptake and internalize very efficiently any foreign element in the body. Thus, for nanosystems whithout a specific targeting, assessing the cytotoxicity on such cell line gives the ability of microgels to be uptaken by the reticulo-endothelial system. It is wellknown that the toxicity of a particle is size-dependent $[54,55]$ and, for cationic systems, toxicity also depends on cation content.[56, 57] In this work, whatever the fraction of the cationic stabilizer in the microgel (4 to $12 \mathrm{wt} \%$ ) or their initial hydrodynamic diameter at $37^{\circ} \mathrm{C}$ (see Table S2), all microgels are biocompatible (cell viabilities above 50\%) in the range up to $2 \mathrm{mg} \cdot \mathrm{mL}^{-1}$, except for RAW cells after $48 \mathrm{~h}$ of incubation as a consequence of their extensive uptake. The incubation time-dependent cytotoxicity has already been observed for other PVCL-based microgels[44] and PVCL-based polymers [58] This might be due to further microgel accumulation around/within cells promoting their death. In addition, the chain length of the cationic polymer used as stabilizer for 
the PVCL microgel synthesis has no relevant impact on the microgel cytotoxicity as similar percentages of cell viability were obtained after incubation of cells with SC1-PX 76 4-E4 and SC1$\mathrm{PX}_{9}$ 4-E4 microgels (Figure 2 and Figure S3 in Supplementary materials), and even for RAW264.7 cells a slight enhancement can be observed at low microgel concentrations (0.005-0.5

$\mathrm{mg} \mathrm{mL}^{-1}$ ) after $24 \mathrm{~h}$ of incubation for the microgel with the largest cationic stabilizer. This is in contrast to previous results showing that the cytotoxicity of the nanosystems increased with the chain length of the cationic polymer. [59-61] This can be explained by the fact that, whatever the chain length of the P(AETAC-X) used as stabilizer for the synthesis of PVCL-based microgels, the final microgels presented similar values of the electrophoretic mobility (SC1-PX 76 4-E4, electrophoretic mobility $=0.42 \times 10^{-8} \mathrm{~m}^{2} / \mathrm{Vs}$ in cationic buffer at $\mathrm{pH} 3$ and $10 \mathrm{mM}$ ionic strength, and $\mathrm{SC} 1-\mathrm{PX} 94-\mathrm{E} 4$, electrophoretic mobility $=0.44 \times 10^{-8} \mathrm{~m}^{2} / \mathrm{Vs}$ in cationic buffer at $\mathrm{pH} 3$ and 10 $\mathrm{mM}$ ionic strength). Finally, just to mention that the extent of microgel crosslinking does not have influence on microgel cell toxicity except at the highest concentrations $\left(>5 \mathrm{mg} \mathrm{mL}^{-1}\right)$ at which the most cross-linked microgels $\left(\mathrm{SC}_{1-\mathrm{PX}} \mathrm{P}_{6}\right.$ 8-E4 and $\mathrm{SC} 1-\mathrm{PX} 76$ 8-E8, Figure S3) induce larger toxicities maybe related to a lower particle elasticity as reported elsewhere.[62]

\section{Monitoring cellular uptake of microgels and uptake pathway.}

Prior to their cellular uptake characterization by means of fluorescence microscopy, the microgels were labeled with the rhodamine $6 \mathrm{G}$ cationic dye. Figure 3 shows fluorescence images of the R6Gloaded microgel cellular uptake in HeLa cells after $3 \mathrm{~h}$ of incubation at $37^{\circ} \mathrm{C}$. 

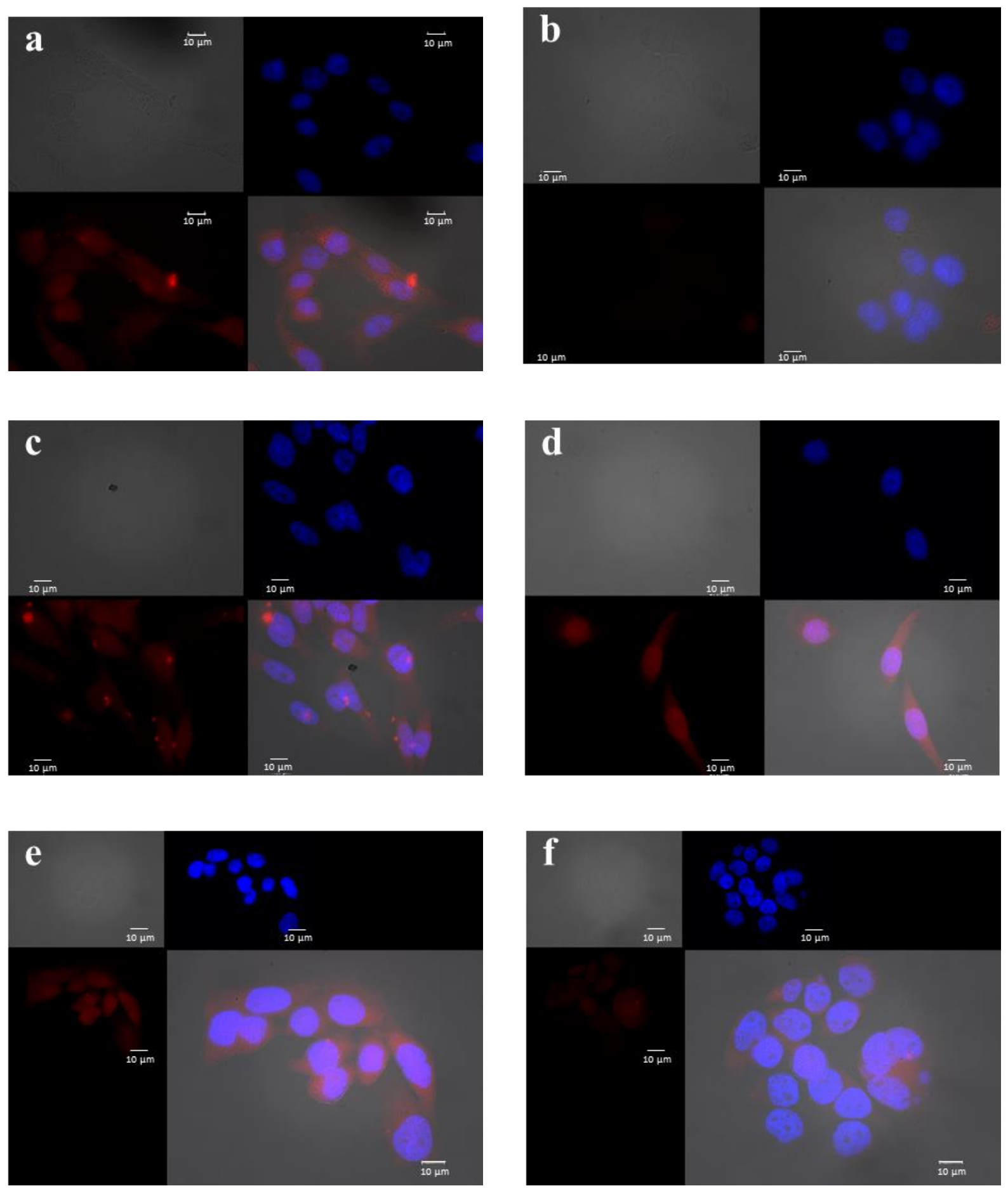

Figure 3. Fluorescence microscopy images of R6G-loaded microgels in HeLa cells after 3 h of incubation at $37^{\circ} \mathrm{C}$ : (a) SC1-PX 76 4-E4, (b) SC1-PX 76 8-E4, (c) SC5-PX 76 4-E4, (d) SC1-PX 76 E8, (e) SC1-PX 16 4-E4, (f) SC1-PX 9 4-E4 microgels in HeLa cells stained with DAPI after $3 \mathrm{~h}$ of incubation at $37^{\circ} \mathrm{C}$. Differential interference contrast (DIC) images (upper left side), DAPI-stained 
cell nuclei (blue, upper right side), R6G fluorescence in cells (red, lower left side) and the merged images (lower right side).

For most of the tested microgels, the DAPI-stained cell nuclei (blue) were surrounded by a diffuse rhodamine fluorescence (red) pattern suggesting a successful cell internalization of the microgels at short time and the subsequent sustained dye release inside the cell cytoplasm.[63] The cationic dye was truly located at the cell cytoplasm and/or in some intracellular compartments, especially endoplasmic reticulum and/or mitochondria, for which R6G is a specific marker. In addition, some few observed pink colored nuclei would indicate overlapping of the fluorescence signal corresponding to microgels/dye located over the nuclei, as observed in the $2 \mathrm{D}$ projections (the dye used is not permeable to the nucleus membrane). The presence of microgel clusters was also visualized via the presence of red dotted spots in the images as a result of microgel aggregation when in contact to the biological medium as a consequence of their positive charges.

At longer incubation times (24 h, Figure S4 in Supplementary materials), rather similar fluorescence patterns as at $3 \mathrm{~h}$ were observed, that is, the DAPI-stained cell nuclei were surrounded by rhodamine fluorescence, suggesting the successful internalization and residence of the microgels/cargo inside cells. The fluorescence intensity of the dye was maintained constant after $24 \mathrm{~h}$ of incubation in agreement with a sustainable release of rhodamine $6 \mathrm{G}$ from the microgels along time, although for some microgels a very small decrease in fluorescence intensity, indicating a certain expulsion of the dye from the cell. However, this point would deserve further studies to rule out any possible contribution from dye quenching and/or degradation. In addition, from a qualitative analysis no relevant differences in uptake levels were noted for the different microgels in terms of their cross-linking ratio, stabilizer chain length and/or initial solids content of their synthesis. On the other hand, it should be highlighted that for high microgel accumulation levels 
inside cells, some few with damaged membranes could clearly be observed confirming the aforementioned statement (Figure S5 in Supplementary materials). Such loss of cell membrane integrity was already observed for cells in contact with other highly cationic nanomaterials.[59] In the present work, much less cells with damaged membrane were observed at $3 \mathrm{~h}$ of incubation rather than at $24 \mathrm{~h}$. This confirms that the microgel accumulation process into cells is timedependent, as already been observed with other PVCL-based microgels.[44, 49, 64]

In order to elucidate how microgels can be internalized into cancerous cells, inhibition experiments of different cell uptake pathways were performed. Endocytosis (the vesicular uptake of extracellular macromolecules) has been established as the main mechanism for the internalization of non-viral vectors into cells.[65] Endocytosis can be classified into two broad categories: phagocytosis (for specialized mammalian cells) and pinocytosis (all cells). Among pinocytic pathways four main mechanisms can be distinguished: clathrin-mediated endocytosis, caveolae, macropinocytosis and clathrin/caveolae-independent endocytosis (Figure S6 in Supplementary materials). Internalization via endocytosis can be inhibited using different cell treatments. A general procedure for hindering endocytic pathways consists in lowering the temperature as endocytosis is an energy-dependent mechanism. The microgel internalization was studied at $4{ }^{\circ} \mathrm{C}$ in order to assess if the internalization mechanism is a chemical-mechanical energy dependent- or a simple diffusion process. The fluorescence images of the R6G-loaded microgel cellular uptake in HeLa cells after $3 \mathrm{~h}$ of incubation at $4^{\circ} \mathrm{C}$ are depicted in Figure 4. 

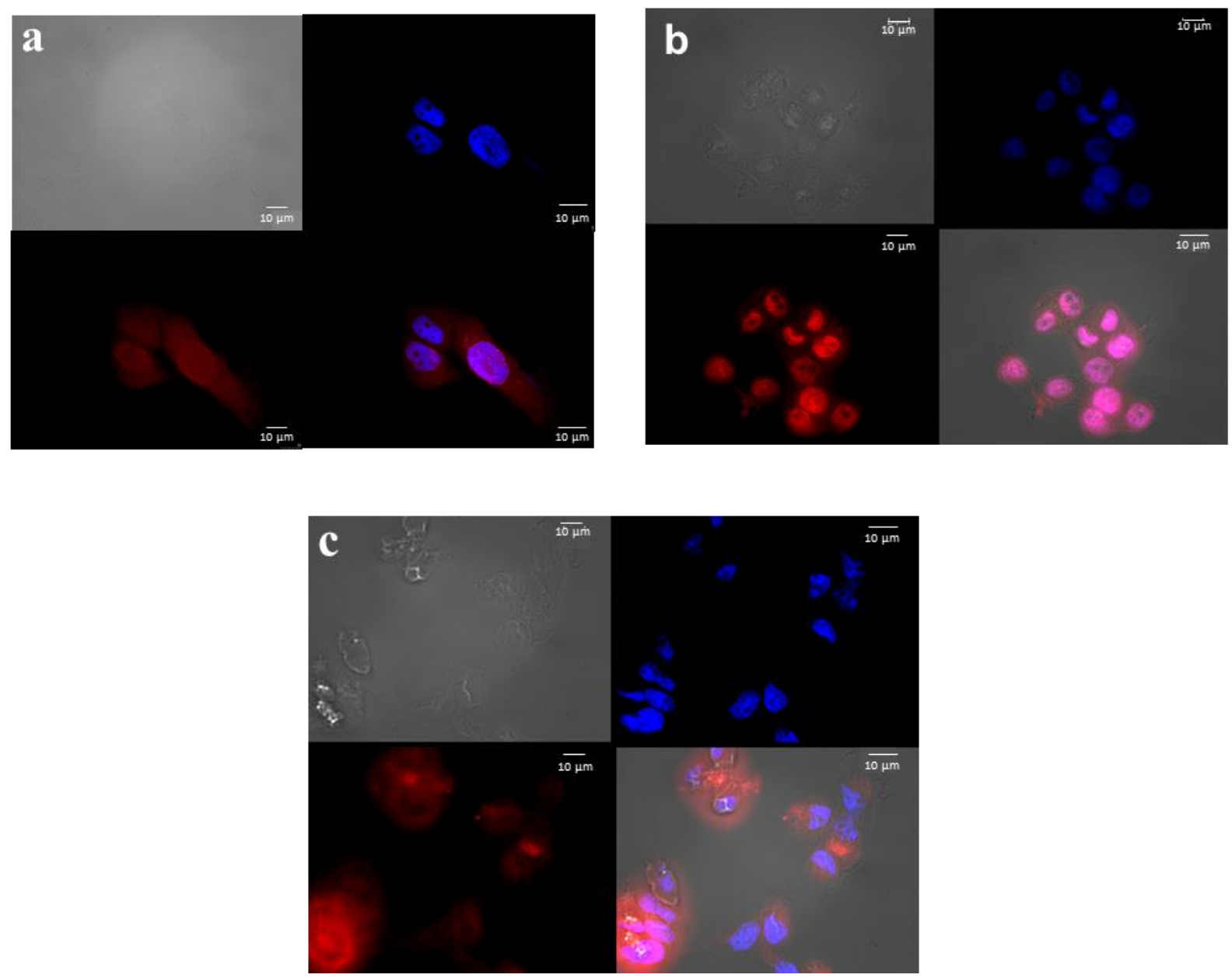

Figure 4. Fluorescence microscopy images of R6G-loaded microgels: (a) SC1-PX76 4-E4, (b) SC1$\mathrm{PX}_{76}$ 8-E8, (c) SC1-PX 4-E4 microgels in HeLa cells stained with DAPI after $3 \mathrm{~h}$ of incubation at $4^{\circ} \mathrm{C}$.

For the three selected PVCL microgels, the internalization process took place satisfactorily at $4^{\circ} \mathrm{C}$, disregarding an energy-dependent uptake pathway for the dye-loaded microgels. Indeed, the R6G release occurred into the cell cytoplasm for all the microgels. Moreover, in some cases, it seems that some few microgel clusters might be surrounding the cell nuclei, as observed by the reconstructed fluorescence image of $\mathrm{SC} 1-\mathrm{PX}_{76}$ 4-E4 microgel in HeLa cell line after $3 \mathrm{~h}$ of incubation at $4^{\circ} \mathrm{C}$ (Figure S7 in Supplementary materials). Nevertheless, further experiments 
would be required to definitively confirm this point. At $4{ }^{\circ} \mathrm{C}, \mathrm{R} 6 \mathrm{G}$ was also released at the cell surroundings (for $\mathrm{SC} 1-\mathrm{PX}_{9} 4-\mathrm{E} 4$ microgel for instance, Figure 4c). For these experiments, it is worth also mentioning the cell density was observed to be slightly lower than for uptake experiments performed at $37^{\circ} \mathrm{C}$, probably as a consequence of some cellular death and their subsequent detachment from the well surface during the washing process. In order to understand which specific protein/mechanism is other involved in the particle incorporation within the cells, it is possible to inhibit specifically a certain endocytic pathway by adding a specific inhibitor for such route.[66] Here, the cellular uptake mechanism of several microgels was investigated using four different inhibitors: two different clathrin-mediated endocytosis specific inhibitors (hypertonic sucrose and chlorpromazine (CPZ)), an inhibitor of macropinicytosis/phagocytosis (cytochalasin D), and an inhibitor of caveolae (nystatin). These inhibitors act dissociating the clathrin lattice, actin and/or caveolae, respectively, impeding the corresponding endocytic pathways. Figure $\mathbf{5}$ and Figure 6 show the fluorescence images of the R6G-loaded microgel cellular uptake in HeLa cells after $3 \mathrm{~h}$ of incubation at $37^{\circ} \mathrm{C}$ in the presence of hypertonic sucrose medium and chlorpromazine, respectively.
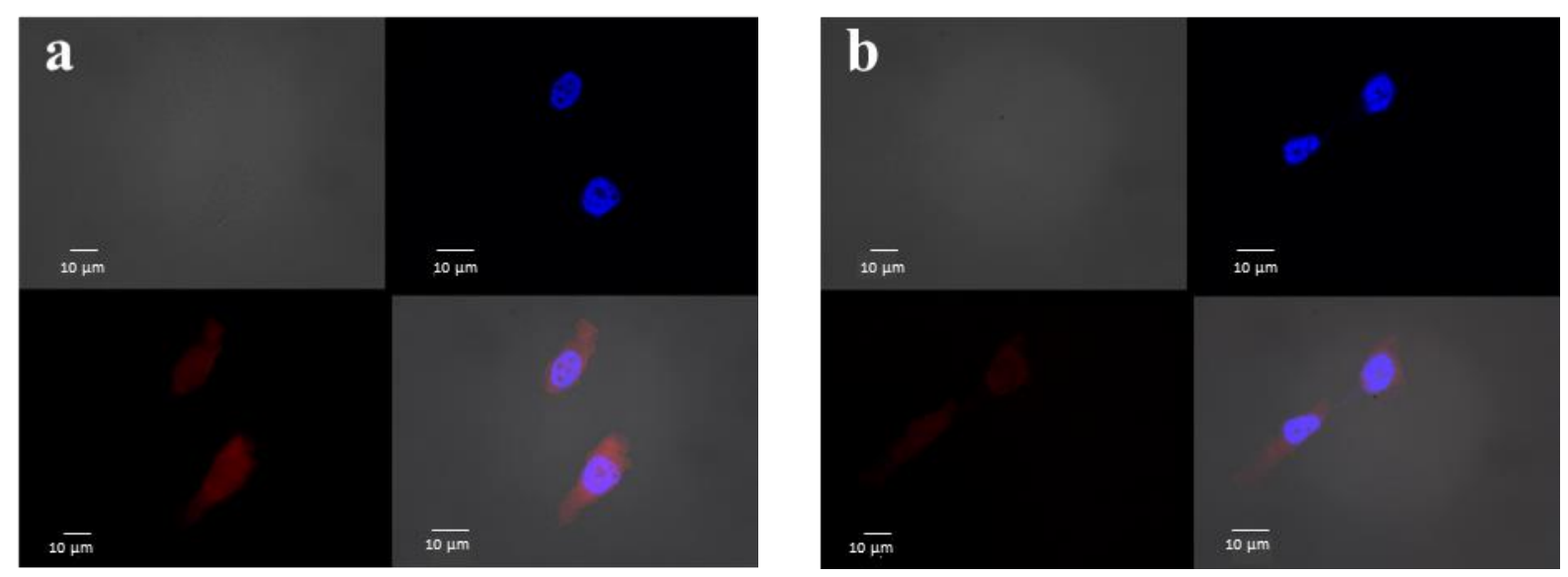

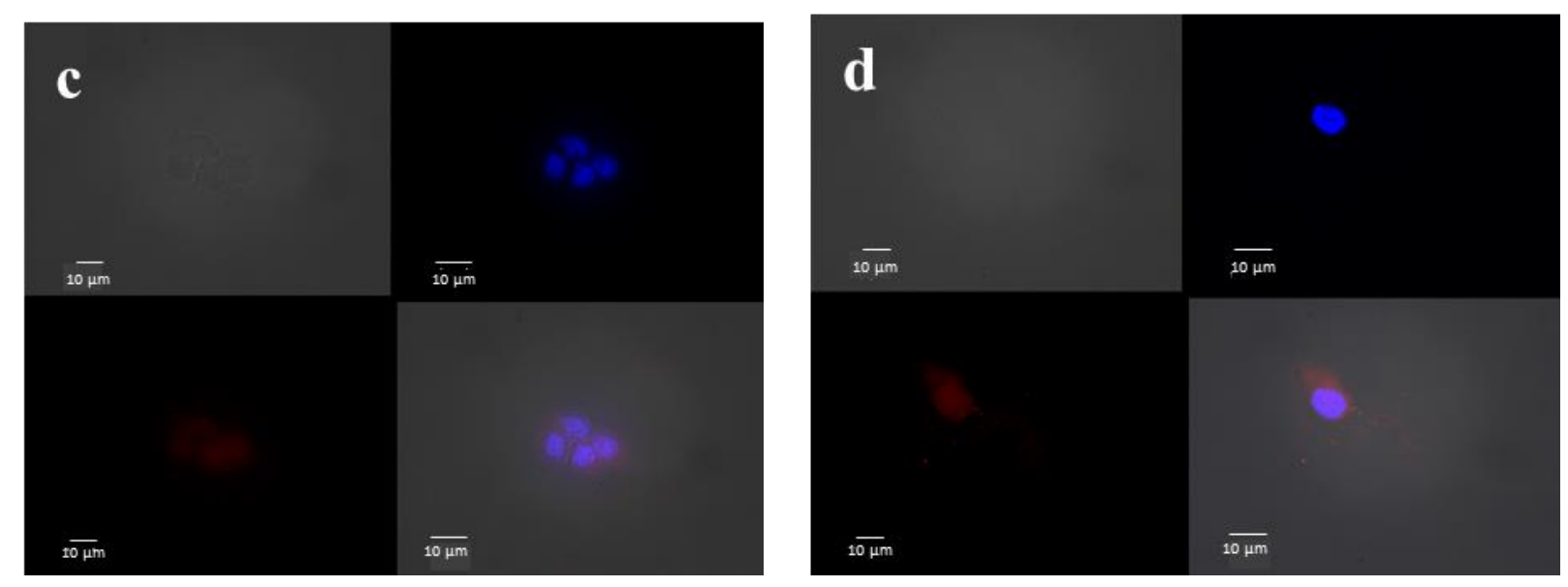

Figure 5. Fluorescence microscopy images of R6G-loaded microgels: (a) SC1-PX 76 4-E4, (b) SC1$\mathrm{PX}_{76}$ 8-E4, (c) SC1-PX 76 8-E8, (d) SC1-PX 9 4-E4 microgels in HeLa cells stained with DAPI after $3 \mathrm{~h}$ of incubation at $37^{\circ} \mathrm{C}$ with hypertonic sucrose medium.
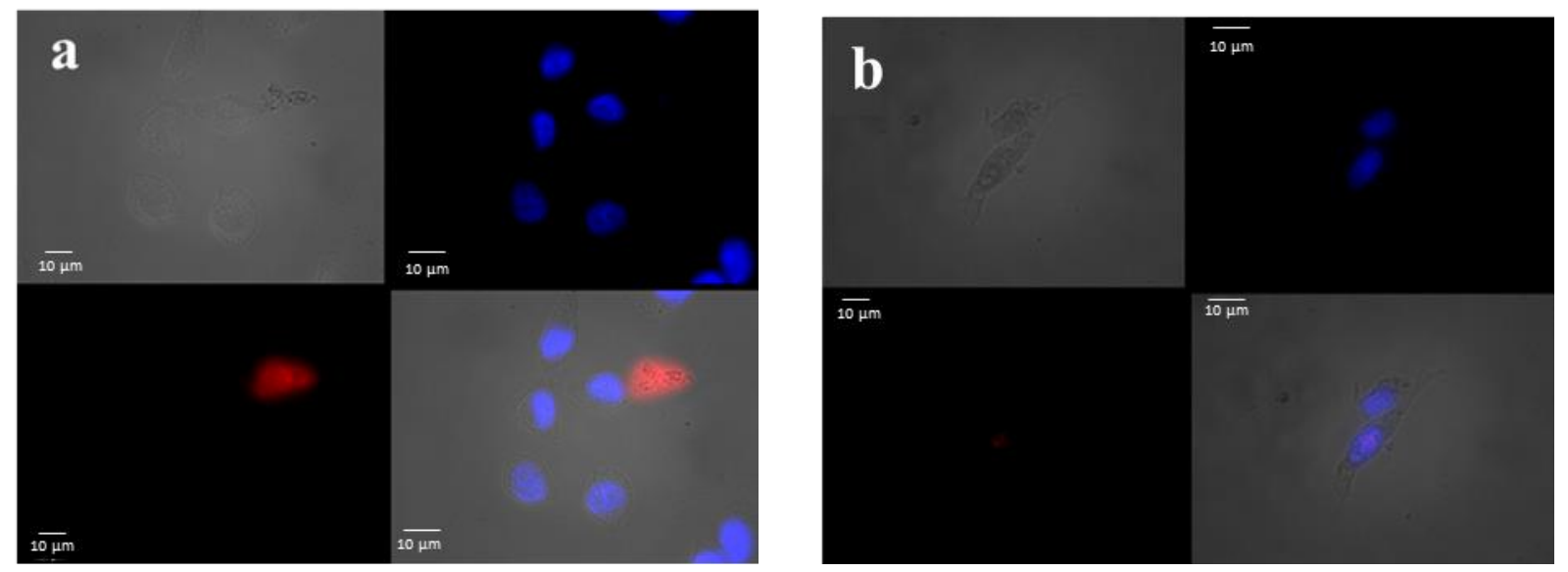

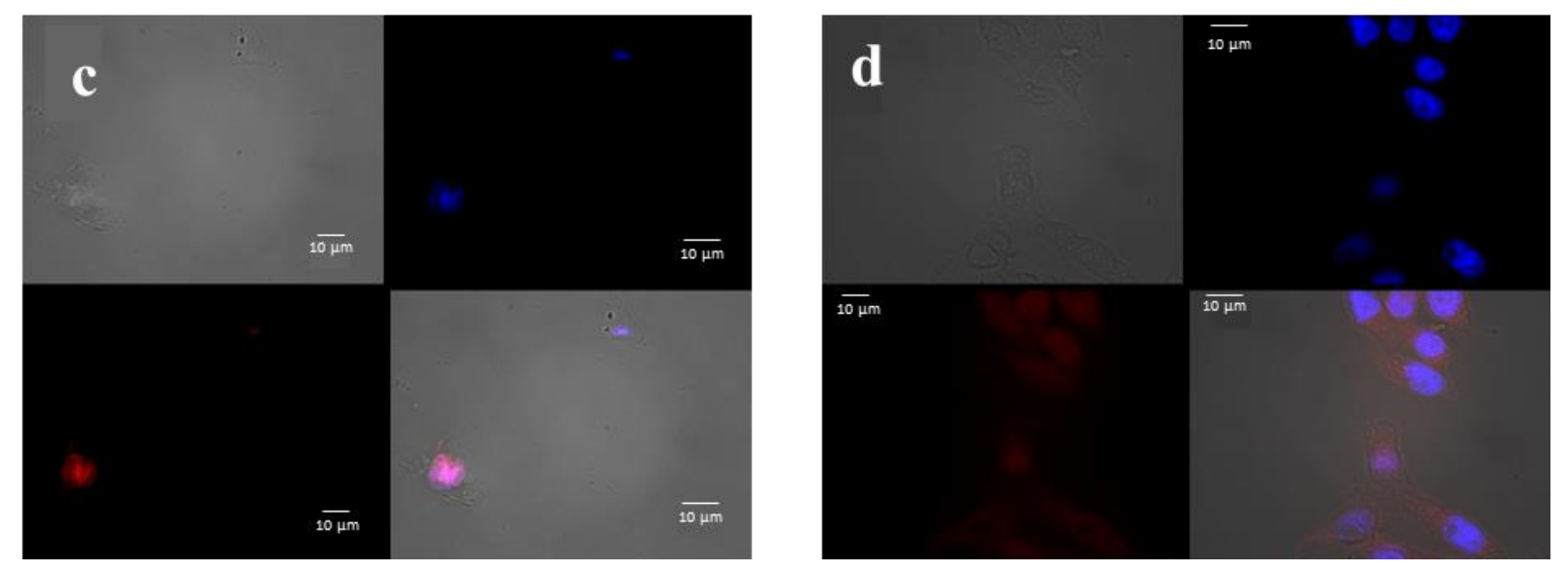

Figure 6. Fluorescence microscopy images of R6G-loaded microgels: (a) SC1-PX 76 4-E4, (b) SC1$\mathrm{PX}_{76}$ 8-E4, (c) SC1-PX 76 8-E8, (d) SC1-PX 9 4-E4 microgels in HeLa cells stained with DAPI after $3 \mathrm{~h}$ of incubation at $37^{\circ} \mathrm{C}$ with chlorpromazine.

Inhibition of clathrins gave rise to a well-observed qualitative reduction in the extent of internalization of dye-loaded microgels as observed from a lower fluorescence signal observed inside cell cytoplasms, especially for microgels coded as SC1-PX 76 8-E4 and SC1-PX 76 8-E8. This points to clathrin as one of the main mechanisms responsible for microgel internalization but not the only one, since some diffuse fluorescence patterns are still observed.

Two other additional internalization routes, macropinocytosis/phagocytosis and caveolae, were additionally analyzed by fluorescence microscopy using the SC1-PX 76 8-E8 microgel. Both cytochalasin $\mathrm{D}$, a polymerization inhibitor of actin which is a protein largely involved in the formation of cell skeleton and mobility, and nystatin, a sterol-binding agent which disassembles caveolae, were used. In these cases, a good level of internalization of the microgels within cells could be observed suggesting that the inhibition of these both routes do not impede the incorporation of the microgel into cells (see Figure S8 and Figure S9 in Supplementary materials). 
Finally, a quantification of the extent of internalization inhibition for microgels SC1-PX 76 4-E4, SC1-PX 76 8-E8 and SC1-PX9 4-E4 loaded with the anticancer DOXO at a concentration of $20 \mu \mathrm{M}$ using the different inhibiting compounds was performed using HeLa cells by evaluating the cell viability by the CCK-8 assay (see part 4 for details of DOXO encapsulation and related efficiency). A maximum cell survival is observed when the clathrin-dependent endocytic pathway is inhibited, either with sucrose or chlorpromazine (CPZ) (Figure 7), which confirms the previous fluorescence microscopy analysis. For cytochalasin D, some increase in viability is observed compared to the control experiment thanks to a certain involvement of cytochalasin D in the clathrin-dependentpathway.[67] For nystatin, cell viabilities were similar as the control experiments, i.e. in the absence of any inhibitor, demonstrating that the macropinicytosis/phagocytosis and caveolae are not the main internalization routes of the present cationic thermoresponsive PVCL microgels.

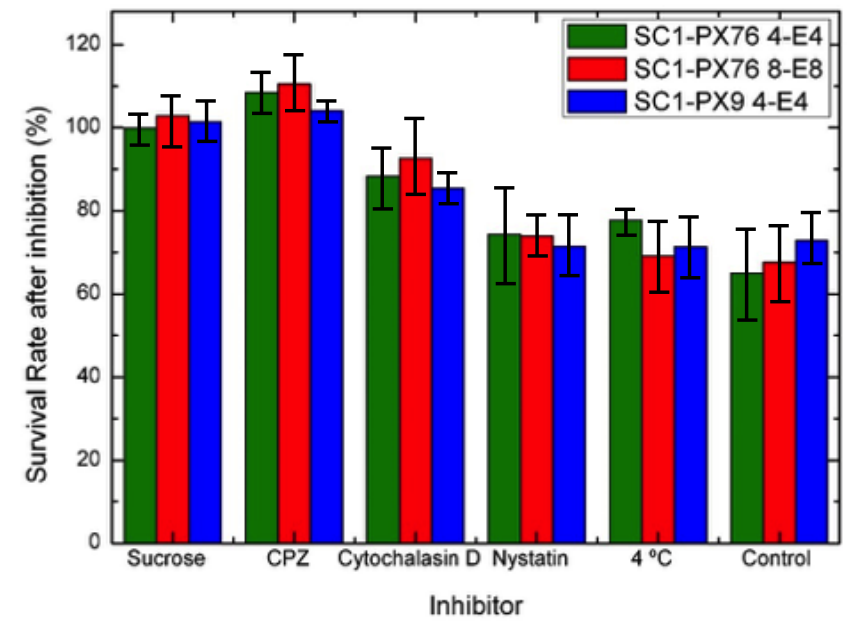

Figure 7. Cellular survival rate after inhibition of different uptake pathways (Maximum uncertainty within $\pm 12 \%)$. 


\section{In vitro cell cytotoxicity assays of DOXO-loaded microgels}

The loading of doxorubicin was performed for some selected microgels, SC1-PX 76 4-E4, SC1-PX 76 8-E4, SC5-PX 76 4-E4, SC1-PX 76 8-E8, SC1-PX 9 4-E4 and SC1-PX 16 4-E4 (Table S1). The chosen drug loading method (see Materials and Methods section) takes advantages of the sponge like nature of the microgels, allowing solute molecules to partition into the porous particle network.[68] DOXO can be incorporated into microgels through electrostatic and/or hydrophobic interactions.[69] The drug loading (D.L.) and entrapment efficiency (E.E.) were calculated according to

Equation 1 and Equation 2, respectively, and the values obtained for the different microgels are presented in Table S3 (Supplementary materials). The values of drug loading and entrapment efficiency are relatively low compared to the values obtained for other PVCL-based nano/microgels, $[44,49,64,70]$. Since the drug loading process was carried out at $\mathrm{pH} 6.5$ for which DOXO is positively charged $(\mathrm{pKa}=8.3),[71]$ electrostatic repulsions between the drug and the cationic PVCL-based microgels might limit the drug encapsulation. Moreover, electrostatic repulsions among DOXO molecules could also reduce the entrapment efficiency. Also, as EGDMA crosslinker is relatively hydrophobic compared to others, it might hinder the penetration of DOXO molecules into the microgel network (which is used in its water soluble hydrochloride salt form).[72] Aguirre et al.[44] studied the loading of DOXO into poly(2diethylaminoethyl)methacrylate (PDEAEMA)-based microgels and PDEAEMA-based core and PVCL-based shell microgels at acidic $\mathrm{pH}$ for which both microgels and DOXO were positively charged. As they used a dextran-based macro-crosslinker, the main driving force to encapsulate DOXO into the microgels was the interaction by H-bonding between the - $\mathrm{OH}$ groups of DOXO and the - $\mathrm{OH}$ groups of the dextran chains. Thus, a high encapsulation efficiency of the drug could be reached (i.e. ranging from 80 to 90\%), even in the presence of electrostatic repulsions between 
the microgels and the drug. In the present work, at the DOXO concentration used $\left(1 \mathrm{mg} \cdot \mathrm{mL}^{-1}\right)$, the levels of entrapment efficiency and drug loading are in a similar range for all the different microgels. Therefore, the structure of the different particles tested does not seem to influence the amount of DOXO encapsulated into the network.

The cumulative DOXO release of the microgels was also studied. DOXO-loaded SC1-PX 76 4-E4, SC1-PX 76 8-E8 and SC1-PX 9 4-E4 microgel dispersions were dialyzed at $37{ }^{\circ} \mathrm{C}$ against different serum-containing (10\% (v/v) FBS) buffer solutions. Sodium acetate/acetic acid (SA) buffer solution ( $\mathrm{pH}$ 5.5) was chosen in order to simulate the extracellular environment of tumoral cancer cells, and phosphate buffer saline (PBS) solution ( $\mathrm{pH} 7.4$ ) was selected to mimic blood serum conditions. Note that at $37^{\circ} \mathrm{C}$ the microgels are collapsed ( $>$ VPTT, see Table S2). The in-vitro cumulative DOXO release at $37^{\circ} \mathrm{C}$ under both pHs is depicted in Figure 8.

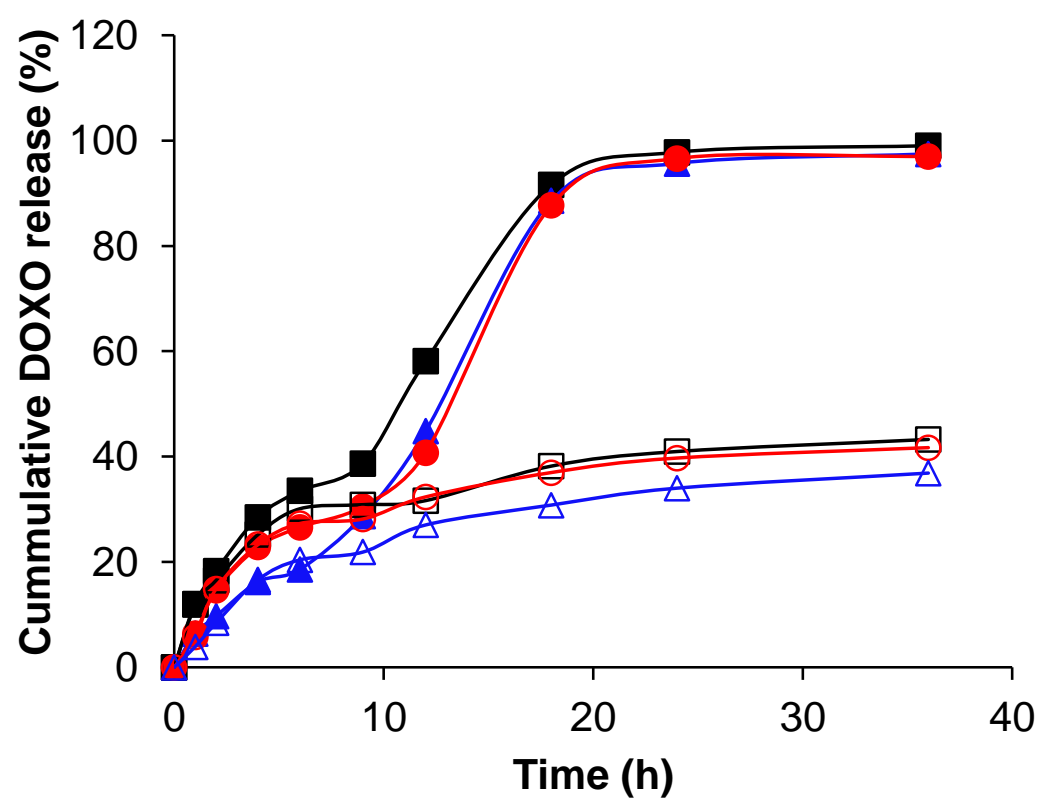

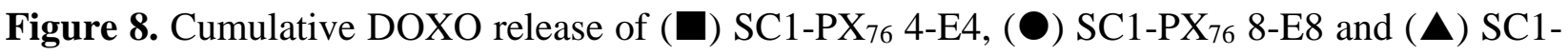
$\mathrm{PX}_{9} 4-\mathrm{E} 4$ microgels at pH 5.5 (closed symbols) and 7.4 (open symbols) in the presence of $10 \%$ (v/v) FBS. Error bars are not displayed for clarity but maximum uncertainties are within $\pm 10 \%$. 
It is well-known that the drug release rate from microgels is theoretically affected by different factors such as the drug diffusion through the microgel particles and the extent of swelling of microgels. In the present case, at $\mathrm{pH} 7.4$ the three selected $\mathrm{SC} 1-\mathrm{PX} 76$ 4-E4, SC1-PX 76 -E8 and $\mathrm{SC}_{1-\mathrm{PX}} 4$-E4 microgels displayed a clear burst release phase within the first $7 \mathrm{~h}$ of incubation where $c a$. 29, 24 and $19 \%$ of the drug is released, followed by a short pseudo-plateau region between $c a .7$ and $10 \mathrm{~h}$. After this incubation period, the release is slightly accelerated to depict a very sustained release pattern at longer incubation times $(>15 \mathrm{~h})$, with total cargo releases between $30-40 \%$ (depending on the microgel) within the time framework of the present experiments ( $c a .37$ h). In contrast, under acidic conditions rather similar release patterns with stair-like profiles can be observed and with larger drug releases than at $\mathrm{pH}$ 7.4. A burst phase is again observed at short incubation times followed by a slowing of the release rate for a short period (more than a true pseudo-plateau region as observed at physiological $\mathrm{pH}$ ). After $c a$. 9-10 $\mathrm{h}$ of incubation an additional abrupt increase in the cumulative release is noted up to $c a .18 \mathrm{~h}$ at which $c a .75-80 \%$ of the cargo is released; thereafter, a plateau region is reached along in which $c a .90 \%$ of the drug is already expelled from the microgels. The presence of an initial burst phase in the release profiles of the present microgels might be related to the adsorption of drug molecules located in the outer layer of the particles, which are released at first; meanwhile, the more sustainable release phase would be controlled by the rate of DOXO release from the microgel core thanks to the hindered diffusion from the highly cross-linked inner part of the microgels. The presence of a slight pseudoplateau/reduction of the release rate between 7-10 h of incubation in Figure 8 might be related to the difference of crosslinking density within the microgel, with a more densely crosslinked core.[36] In addition, important differences in the release extents between acidic and basic physiological conditions can be observed. At this point, it is important to note that the cationic 
stabilizer used for the synthesis of the microgels is permanently charged and, thus, insensitive to $\mathrm{pH}$ changes. Therefore, the larger cumulative releases observed at $\mathrm{pH} 5.5$ might be attributed to the fact that, at acidic conditions, amine groups of DOXO molecules are protonated (i.e. positively charged). As the hydrophilicity of DOXO molecules is enhanced at acidic $\mathrm{pH}$, the affinity of the drug with the microgel hydrophobic core might be reduced, enhancing the diffusion out of the particle.[73] Finally, no remarkable differences in DOXO release kinetics were observed between the three selected microgels. This would hence suggest that neither the extent of polymer stabilizer nor the amount of crosslinker would have a strong impact on the release profiles, at least in the range within the tested particles. As the interactions were mainly non-covalent, it was expected that the delivery would be governed by diffusion, which is affected by the swelling capability of the microgels and their interactions with the drug (especially electrostatic repulsion at acidic conditions). Since the used microgels showed very similar swelling-deswelling behavior, an analogous DOXO release kinetics was observed in all cases.

Cell viability of DOXO-loaded microgels was then studied at different microgel concentrations (from 0.1 to $2 \mathrm{mg} \cdot \mathrm{mL}^{-1}$ ), thus at different DOXO concentrations, in both HeLa and RAW cell lines after $24 \mathrm{~h}$ of incubation (Figure 9). For each microgel, the concentration of DOXO was calculated from the microgel weight concentration and the entrapment efficiency (see Table S3) according to Equation 4. The results are given in Table S4. For HeLa cells, the $\mathrm{IC}_{50}$ (i.e, the concentration of drug required to reduce cell growth by 50\%) of free DOXO after $24 \mathrm{~h}$ of incubation was $5.5 \mu \mathrm{M}$ (see Supplementary materials). Therefore, for all microgels at concentrations above $0.1 \mathrm{mg} \cdot \mathrm{mL}^{-1}$, the DOXO concentrations loaded inside are above the minimum DOXO concentration providing cytotoxicity activities in vitro. The bare microgels were biocompatible and did not inhibit growth of both types of cell lines in the range of the studied microgel concentrations $\left(0.1\right.$ to $2 \mathrm{mg}$. $\left.\mathrm{mL}^{-1}\right)$ as mentioned previously. In contrast, DOXO-loaded microgels exhibit higher cytotoxicity due to the 
effect of the drug (Figure 9). As expected, DOXO-loaded microgel cytotoxicity is dose-dependent as cell viability decreases by increasing the concentration of DOXO-loaded microgels and, hence, by increasing the concentration of DOXO. For the highest DOXO concentration used, the decrease of cell viability in the presence of DOXO-loaded microgels was more pronounced in the case of HeLa cells than for RAW ones. This result could be explained by the fact that RAW cells proliferate quicker than HeLa cells leading to a higher percentage of viable cells at the same percentage of dead cells. Additionally, HeLa cells are more sensitive to DOXO-loaded microgels as a result of their higher metabolic activity, which may lead to larger particle uptakes (confirmed by the cellular uptake experiments presented previously), and, hence, allowing a larger DOXO concentration inside the cells. Figure S10 reports the cell viability of HeLa cells after incubation for $24 \mathrm{~h}$ with free DOXO and the different DOXO-loaded microgels in the same range of initial loaded DOXO concentrations (from 3 to $30 \mu \mathrm{M}$ ).
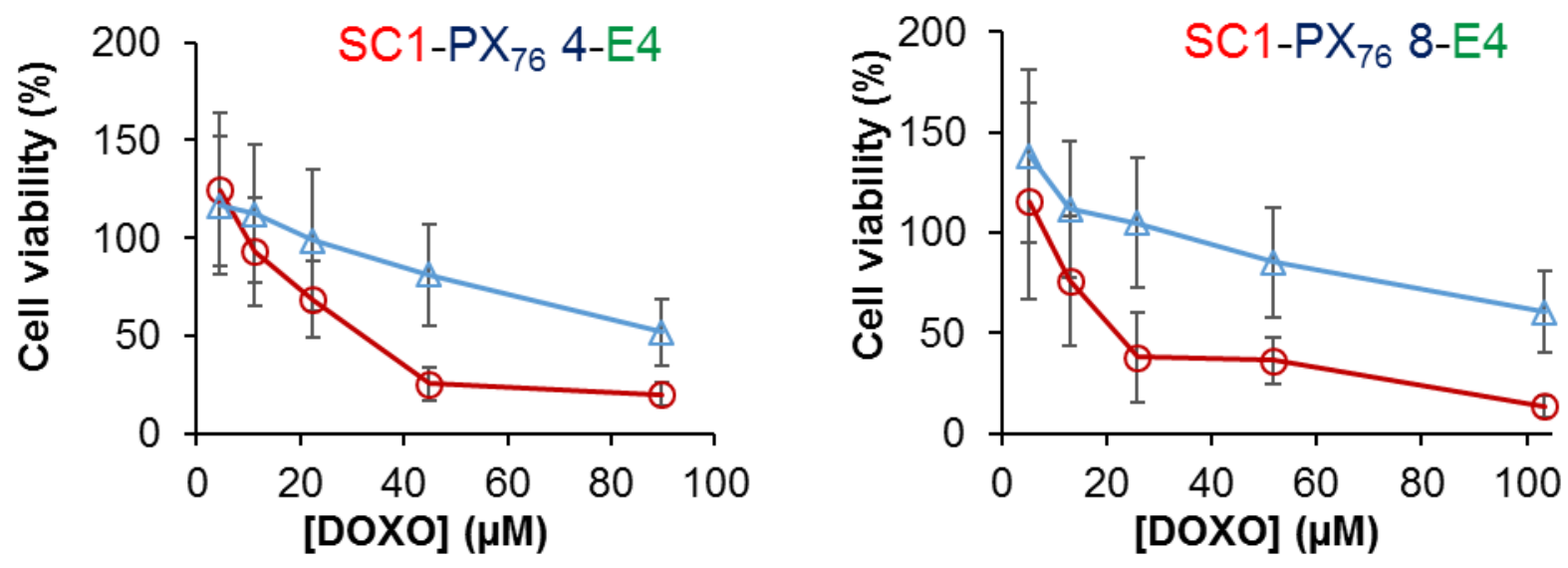

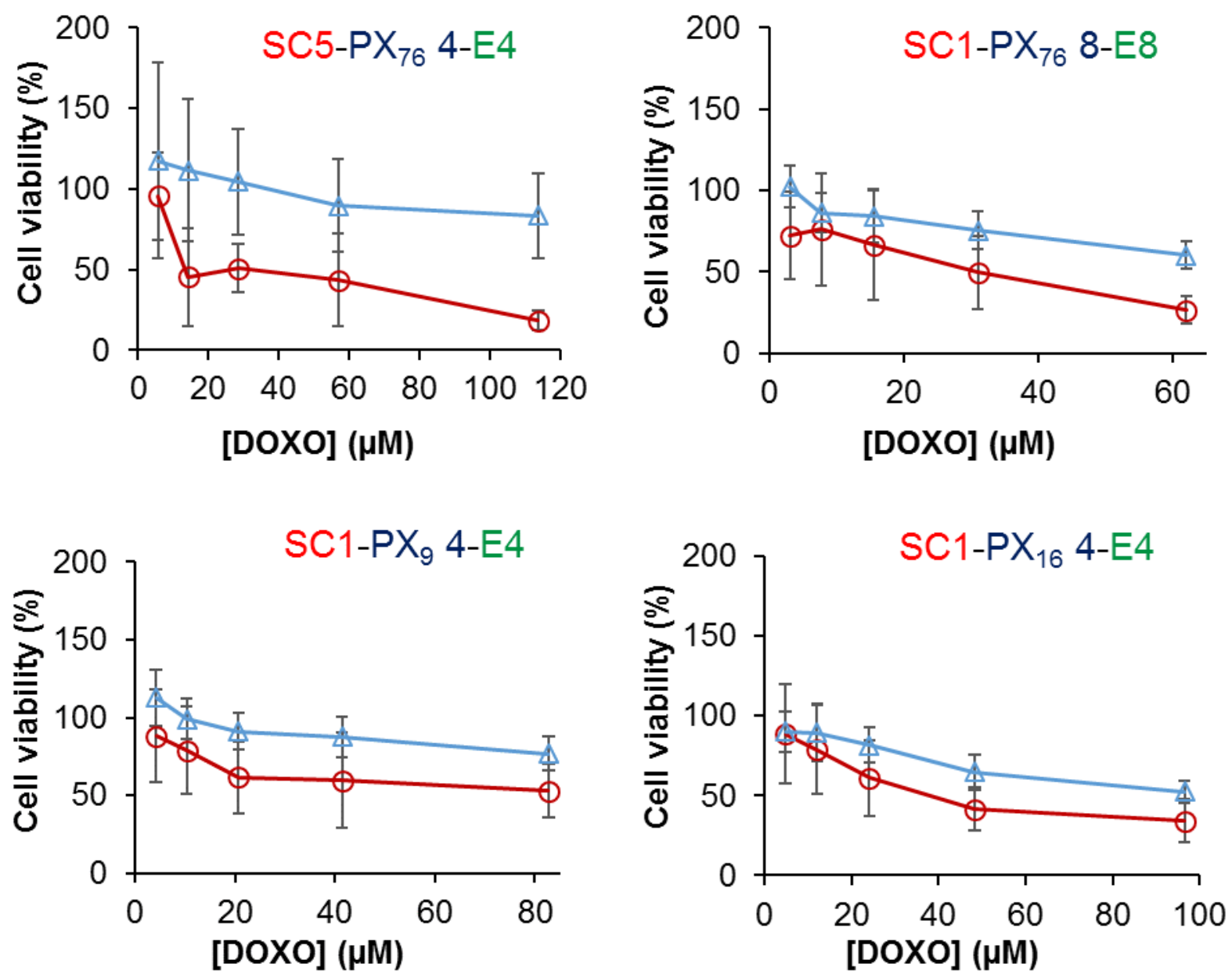

Figure 9. Cell viability of: $(\mathbf{O})$ HeLa and $(\mathbf{\Delta})$ RAW cell lines as a function of DOXO concentration after $24 \mathrm{~h}$ of incubation at $37^{\circ} \mathrm{C}$.

For a given DOXO concentration, the level of cytotoxicity is in the same range for all the series of microgels, without relevant apparent influence of their structure and/or compositons in agreement with previous observation, and with an expected increase of cytotoxicity by increasing the DOXO concentration. It should be noted that the viability of HeLa cells is higher when incubated in the presence of DOXO-loaded microgels than with free DOXO as a consequence of the much more sustained release of DOXO from the microgels. Indeed, and as observed for other PVCL-based microgels, the release of the drug from the microgels to the cells through diffusion is a timedependent and sustained process.[44, 49, 70] 


\section{Conclusions}

In summary, a series of biocompatible thermo-responsive microgels with covalently anchored cationic shells were synthesized directly in water by emulsion polymerization. The stability of the bare PVCL-based microgels was studied after incubation for 13 days at $37^{\circ} \mathrm{C}$ in different biological mimicking media revealing that the incubation time before aggregation should be carefully considered. Cytotoxicity assays of the bare PVCL-based microgels on HeLa and RAW cells indicated that all the microgel particles were biocompatible for concentration ranging from 0.005 to $2 \mathrm{mg} \cdot \mathrm{mL}^{-1}$. The inhibition of cell's growth was both a time and a dose-dependent process. The successful cellular uptake of the microgels is time-dependent as well as the release of R6G into the cell cytoplasm, with an apparently sustained release profile of the dye from the microgels into the cells. The mechanism of internalization of microgels and the interactions between microgels and HeLa cells was investigated through blocking different endocytic uptake pathways. It could be observed that inhibition of clathrins gave rise to a reduction in the extent of internalization of R6Gloaded microgels demonstrating that this pathway was one of the main mechanisms responsible for microgel internalization. Finally, doxorubicin anticancer model drug was loaded into some cationic core-shell thermoresponsive PVCL microgels. The DOXO-loaded microgels exhibited higher cytotoxicities on HeLa cells than bare PVCL microgels due to the effect of the drug. At similar initial DOXO concentrations and for incubation at $37^{\circ} \mathrm{C}$ for $24 \mathrm{~h}$, the viability of HeLa cells was slightly higher when incubated in the presence of DOXO-loaded microgels than with free DOXO as a consequence of the sustained release of DOXO from the microgels, confirming the suitability of the cationic PVCL-based microgels as chemotherapeutic drug delivery nanocarriers.

\section{Acknowledgements}


The French ministry of research, the University Pau \& Pays Adour (ED Sciences 211) and the University of the Basque Country UPV/EHU are acknowledged for funding L.E.'s PhD work performed under a joint doctorate program. P.T. also thanks MINECO by project MAT201680266-R, and Xunta de Galicia for supporting Agrupación Estratégica de Materiales, Action Grant ED431E 2018/08, and Consolidación de Grupos de Referencia Competitiva, Grant ED431C 2018/26. ERDF are also acknowledged. The Equipex Xyloforest program (ANR-10-EQPX-16 XYLOFOREST) is acknowledged for NMR probe funding.

Appendix A. Supplementary material content. Synthesis and characterization of PVCL-based microgels, Variation of the hydrodynamic diameter of bare microgels at $37^{\circ} \mathrm{C}$ in different biological mimicking media, effect of concentrations of $\mathrm{KBr}$ salt on the $D_{\mathrm{h}}$ versus $\mathrm{T}^{\circ}$ plots, Cell viability of HeLa and RAW cell lines vs concentration of microgels, Fluorescence microscopy images of R6G-loaded microgels after $24 \mathrm{~h}$ of incubation, scheme of cellular uptake pathways, Fluorescence microscopy images of R6G-loaded SC1-PX 76 8-E8 microgels after $3 \mathrm{~h}$ of incubation at $37^{\circ} \mathrm{C}$ with cytochalasin $\mathrm{D}$ or nystatin, Tables with values of entrapment efficiency and drug loading and DOXO concentration for the different microgels.

\section{References}

[1] Y. Wang, H. Xu, L. Ma, Recent advances of thermally responsive nanogels for cancer therapy, Therapeutic delivery 6(10) (2015) 1157-69.

[2] J. Ramos, J. Forcada, R. Hidalgo-Alvarez, Cationic polymer nanoparticles and nanogels: from synthesis to biotechnological applications, Chemical reviews 114(1) (2014) 367-428.

[3] S. Mura, J. Nicolas, P. Couvreur, Stimuli-responsive nanocarriers for drug delivery, Nat Mater 12(11) (2013) 991-1003.

[4] L. Shang, K. Nienhaus, G.U. Nienhaus, Engineered nanoparticles interacting with cells: size matters, Journal of nanobiotechnology 12 (2014) 5.

[5] A.Z. Wilczewska, K. Niemirowicz, K.H. Markiewicz, H. Car, Nanoparticles as drug delivery systems, Pharmacological Reports 64(5) (2012) 1020-1037. 
[6] C. Dhand, M.P. Prabhakaran, R.W. Beuerman, R. Lakshminarayanan, N. Dwivedi, S. Ramakrishna, Role of size of drug delivery carriers for pulmonary and intravenous administration with emphasis on cancer therapeutics and lung-targeted drug delivery, RSC Advances 4(62) (2014) 32673.

[7] R.A. Petros, J.M. DeSimone, Strategies in the design of nanoparticles for therapeutic applications, Nature reviews. Drug discovery 9(8) (2010) 615-27.

[8] M.A. Dobrovolskaia, S.E. McNeil, Immunological properties of engineered nanomaterials, Nature nanotechnology 2(8) (2007) 469-78.

[9] J.K. Oh, R. Drumright, D.J. Siegwart, K. Matyjaszewski, The development of microgels/nanogels for drug delivery applications, Progress in Polymer Science 33(4) (2008) 448-477.

[10] S.V. Vinogradov, Nanogels in the race for drug delivery, Nanomedicine 5(2) (2010) 165-8.

[11] B.R. Saunders, N. Laajam, E. Daly, S. Teow, X. Hu, R. Stepto, Microgels: From responsive polymer colloids to biomaterials, Advances in colloid and interface science 147-148 (2009) 251-62.

[12] S. Lu, K.G. Neoh, C. Huang, Z. Shi, E.-T. Kang, Polyacrylamide hybrid nanogels for targeted cancer chemotherapy via co-delivery of gold nanoparticles and MTX, J. Colloid Interface Sci. 412 (2013) 46-55.

[13] P. Baipaywad, N. Udomluck, S.-G. Pyo, H.H. Park, H. Park, Fabrication of Nanogels for Delivery of Molecules, Journal of Nanoscience and Nanotechnology 14(10) (2014) 7363-7373.

[14] M. Karimi, A. Ghasemi, P. Sahandi Zangabad, R. Rahighi, S.M. Moosavi Basri, H. Mirshekari, M. Amiri, Z. Shafaei Pishabad, A. Aslani, M. Bozorgomid, D. Ghosh, A. Beyzavi, A. Vaseghi, A.R. Aref, L. Haghani, S. Bahrami, M.R. Hamblin, Smart micro/nanoparticles in stimulus-responsive drug/gene delivery systems, Chemical Society reviews 45(5) (2016) 1457-501.

[15] E. Mauri, G.M.F. Chincarini, R. Rigamonti, L. Magagnin, A. Sacchetti, F. Rossi, Modulation of electrostatic interactions to improve controlled drug delivery from nanogels, Mater. Sci. Eng. C-Mater. Biol. Appl. 72 (2017) 308-315.

[16] P.P. Yi, Y.F. Wang, P.X. He, Y. Zhan, Z.G. Sun, Y.L. Li, Y.H. Zhang, Study on beta-cyclodextrincomplexed nanogels with improved thermal response for anticancer drug delivery, Mater. Sci. Eng. CMater. Biol. Appl. 78 (2017) 773-779.

[17] Y.K. Ma, Y.X. Ge, L.B. Li, Advancement of multifunctional hybrid nanogel systems: Construction and application in drug co-delivery and imaging technique, Mater. Sci. Eng. C-Mater. Biol. Appl. 71 (2017) 1281-1292.

[18] L.A. Lyon, Z. Meng, N. Singh, C.D. Sorrell, A. St John, Thermoresponsive microgel-based materials, Chemical Society reviews 38(4) (2009) 865-74.

[19] J.E. Wong, A.K. Gaharwar, D. Mueller-Schulte, D. Bahadur, W. Richtering, Dual-stimuli responsive PNiPAM microgel achieved via layer-by-layer assembly: Magnetic and thermoresponsive, J. Colloid Interface Sci. 324(1-2) (2008) 47-54.

[20] N.M.B. Smeets, T. Hoare, Designing responsive microgels for drug delivery applications, Journal of Polymer Science, Part A: Polymer Chemistry 51(14) (2013) 3027-3043.

[21] B. Sung, C. Kim, M.H. Kim, Biodegradable colloidal microgels with tunable thermosensitive volume phase transitions for controllable drug delivery, J. Colloid Interface Sci. 450 (2015) 26-33.

[22] B. Olalde, N. Garmendia, V. Saez-Martinez, N. Argarate, P. Nooeaid, F. Morin, A.R. Boccaccini, Multifunctional bioactive glass scaffolds coated with layers of poly(D,L-lactide-co-glycolide) and poly(nisopropylacrylamide-co-acrylic acid) microgels loaded with vancomycin, Mater. Sci. Eng. C-Mater. Biol. Appl. 33(7) (2013) 3760-3767.

[23] G.R. Bardajee, Z. Hooshyar, M. Farsi, A. Mobini, G. Sang, Synthesis of a novel thermo/pH sensitive nanogel based on salep modified graphene oxide for drug release, Mater. Sci. Eng. C-Mater. Biol. Appl. 72 (2017) 558-565.

[24] J. Ramos, A. Imaz, J. Forcada, Temperature-sensitive nanogels: poly(N-vinylcaprolactam) versus poly(N-isopropylacrylamide), Polym. Chem. 3(4) (2012) 852-856.

[25] J. Liu, A. Debuigne, C. Detrembleur, C. Jerome, Poly(N-vinylcaprolactam): a thermoresponsive macromolecule with promising future in biomedical field, Advanced healthcare materials 3(12) (2014) 1941-68. 
[26] G. Aguirre, E. Villar-Alvarez, A. Gonzalez, J. Ramos, P. Taboada, J. Forcada, Biocompatible StimuliResponsive Nanogels for Controlled Antitumor Drug Delivery, Journal of Polymer Science Part A-Polymer Chemistry 54(12) (2016) 1694-1705.

[27] H. Peng, X.B. Huang, A. Oppermann, A. Melle, L. Weger, M. Karperien, D. Woll, A. Pich, A facile approach for thermal and reduction dual-responsive prodrug nanogels for intracellular doxorubicin delivery, J. Mat. Chem. B 4(47) (2016) 7572-7583.

[28] W.J. Sun, S. Thies, J.L. Zhang, C. Peng, G.Y. Tang, M.W. Shen, A. Pich, X.Y. Shi, GadoliniumLoaded Poly(N-vinylcaprolactam) Nanogels: Synthesis, Characterization, and Application for Enhanced Tumor MR Imaging, ACS Appl. Mater. Interfaces 9(4) (2017) 3411-3418.

[29] A.S. Sonzogni, G. Yealland, M. Kar, S. Wedepohl, L.M. Gugliotta, V.D.G. Gonzalez, S. Hedtrich, M. Calderon, R.J. Minari, Effect of Delivery Platforms Structure on the Epidermal Antigen Transport for Topical Vaccination, Biomacromolecules 19(12) (2018) 4607-4616.

[30] S. Dincer, M. Turk, E. Piskin, Intelligent polymers as nonviral vectors, Gene therapy 12 Suppl 1 (2005) S139-45.

[31] Y. Yue, C. Wu, Progress and perspectives in developing polymeric vectors for in vitro gene delivery, Biomater. Sci. 1(2) (2013) 152-170.

[32] H. Yin, R.L. Kanasty, A.A. Eltoukhy, A.J. Vegas, J.R. Dorkin, D.G. Anderson, Non-viral vectors for gene-based therapy, Nature reviews. Genetics 15(8) (2014) 541-55.

[33] L. Bui, S. Abbou, E. Ibarboure, N. Guidolin, C. Staedel, J.J. Toulme, S. Lecommandoux, C. Schatz, Encapsidation of RNA-Polyelectrolyte Complexes with Amphiphilic Block Copolymers: Toward a New Self-Assembly Route, Journal of the American Chemical Society 134(49) (2012) 20189-20196.

[34] H.T. Ho, S. Pascual, V. Montembault, N. Casse, L. Fontaine, Innovative well-defined primary aminebased polyacrylates for plasmid DNA complexation, Polymer Chemistry 5(19) (2014) 5542-5545.

[35] P. Kodlekere, A.L. Cartelle, L.A. Lyon, Design of functional cationic microgels as conjugation scaffolds, RSC Advances 6(38) (2016) 31619-31631.

[36] L. Etchenausia, E. Deniau, A. Brulet, J. Forcada, M. Save, Cationic Thermoresponsive Poly(Nvinylcaprolactam) Microgels Synthesized by Emulsion Polymerization Using a Reactive Cationic MacroRAFT Agent, Macromolecules 51(7) (2018) 2551-2563.

[37] D. Chen, P. Song, F. Jiang, X. Meng, W. Sui, C. Shu, L.J. Wan, pH-responsive mechanism of a deoxycholic acid and folate comodified chitosan micelle under cancerous environment, The journal of physical chemistry. B 117(5) (2013) 1261-8.

[38] Q. Jiang, C. Song, J. Nangreave, X. Liu, L. Lin, D. Qiu, Z.G. Wang, G. Zou, X. Liang, H. Yan, B. Ding, DNA origami as a carrier for circumvention of drug resistance, Journal of the American Chemical Society 134(32) (2012) 13396-403.

[39] H. Hillaireau, P. Couvreur, Nanocarriers' entry into the cell: relevance to drug delivery, Cellular and molecular life sciences : CMLS 66(17) (2009) 2873-96.

[40] C.M. Wiethoff, C.R. Middaugh, Barriers to nonviral gene delivery, Journal of pharmaceutical sciences 92(2) (2003) 203-17.

[41] S.R. Van Tomme, B.G. De Geest, K. Braeckmans, S.C. De Smedt, F. Siepmann, J. Siepmann, C.F. van Nostrum, W.E. Hennink, Mobility of model proteins in hydrogels composed of oppositely charged dextran microspheres studied by protein release and fluorescence recovery after photobleaching, Journal of controlled release : official journal of the Controlled Release Society 110(1) (2005) 67-78.

[42] N. Belmadi, P. Midoux, P. Loyer, C. Passirani, C. Pichon, T. Le Gall, P.A. Jaffres, P. Lehn, T. Montier, Synthetic vectors for gene delivery: An overview of their evolution depending on routes of administration, Biotechnology journal 10(9) (2015) 1370-89.

[43] L. Nuhn, S. Gietzen, K. Mohr, K. Fischer, K. Toh, K. Miyata, Y. Matsumoto, K. Kataoka, M. Schmidt, R. Zentel, Aggregation behavior of cationic nanohydrogel particles in human blood serum, Biomacromolecules 15(4) (2014) 1526-33.

[44] G. Aguirre, E. Villar-Alvarez, A. González, J. Ramos, P. Taboada, J. Forcada, Biocompatible stimuliresponsive nanogels for controlled antitumor drug delivery, Journal of Polymer Science Part A: Polymer Chemistry 54(12) (2016) 1694-1705. 
[45] H. Kawaguchi, K. Fujimoto, Y. Mizuhara, Hydrogel microspheres III. Temperature-dependent adsorption of proteins on poly-N-isopropylacrylamide hydrogel microspheres, Colloid \& Polymer Science 270(1) (1992) 53-57.

[46] T. Trongsatitkul, B.M. Budhlall, Temperature dependence of serum protein adsorption in PEGylated PNIPAm microgels, Colloids and Surfaces B: Biointerfaces 103 (2013) 244-252.

[47] I.O. Standardization, Tests for in-vitro cytotoxicity, 2009.

[48] Q. Xiong, M. Zhang, Z. Zhang, W. Shen, L. Liu, Q. Zhang, Anti-tumor drug delivery system based on cyclodextrin-containing $\mathrm{pH}$-responsive star polymer: in vitro and in vivo evaluation, International journal of pharmaceutics 474(1-2) (2014) 232-40.

[49] Y. Wang, J. Nie, B. Chang, Y. Sun, W. Yang, Poly(vinylcaprolactam)-based biodegradable multiresponsive microgels for drug delivery, Biomacromolecules 14(9) (2013) 3034-46.

[50] M. Prabaharan, J.J. Grailer, D.A. Steeber, S. Gong, Thermosensitive micelles based on folateconjugated poly(N-vinylcaprolactam)-block-poly(ethylene glycol) for tumor-targeted drug delivery, Macromolecular bioscience 9(8) (2009) 744-53.

[51] S. Shah, A. Pal, R. Gude, S. Devi, Synthesis and characterization of thermo-responsive copolymeric nanoparticles of poly(methyl methacrylate-co-N-vinylcaprolactam), European Polymer Journal 46(5) (2010) 958-967.

[52] M.E. Cavet, K.L. Harrington, K.R. VanDerMeid, K.W. Ward, J.Z. Zhang, Comparison of the effect of multipurpose contact lens solutions on the viability of cultured corneal epithelial cells, Contact lens \& anterior eye : the journal of the British Contact Lens Association 32(4) (2009) 171-5.

[53] Slowing, II, C.W. Wu, J.L. Vivero-Escoto, V.S. Lin, Mesoporous silica nanoparticles for reducing hemolytic activity towards mammalian red blood cells, Small 5(1) (2009) 57-62.

[54] R. Podila, J.M. Brown, Toxicity of engineered nanomaterials: a physicochemical perspective, Journal of biochemical and molecular toxicology 27(1) (2013) 50-5.

[55] S. Naahidi, M. Jafari, F. Edalat, K. Raymond, A. Khademhosseini, P. Chen, Biocompatibility of engineered nanoparticles for drug delivery, Journal of controlled release : official journal of the Controlled Release Society 166(2) (2013) 182-94.

[56] M.C. Garnett, Gene-Delivery Systems Using Cationic Polymers, Critical Reviews ${ }^{\mathrm{TM}}$ in Therapeutic Drug Carrier Systems 16(2) (1999) 61.

[57] K. McAllister, P. Sazani, M. Adam, M.J. Cho, M. Rubinstein, R.J. Samulski, J.M. DeSimone, Polymeric Nanogels Produced via Inverse Microemulsion Polymerization as Potential Gene and Antisense Delivery Agents, Journal of the American Chemical Society 124(51) (2002) 15198-15207.

[58] H. Vihola, A. Laukkanen, L. Valtola, H. Tenhu, J. Hirvonen, Cytotoxicity of thermosensitive polymers poly(N-isopropylacrylamide), poly(N-vinylcaprolactam) and amphiphilically modified poly(Nvinylcaprolactam), Biomaterials 26(16) (2005) 3055-64.

[59] H. Zhang, T. Xia, H. Meng, M. Xue, S. George, Z. Ji, X. Wang, R. Liu, M. Wang, B. France, R. Rallo, R. Damoiseaux, Y. Cohen, K.A. Bradley, J.I. Zink, A.E. Nel, Differential expression of syndecan-1 mediates cationic nanoparticle toxicity in undifferentiated versus differentiated normal human bronchial epithelial cells, ACS nano 5(4) (2011) 2756-69.

[60] J. Cai, Y. Yue, D. Rui, Y. Zhang, S. Liu, C. Wu, Effect of Chain Length on Cytotoxicity and Endocytosis of Cationic Polymers, Macromolecules 44(7) (2011) 2050-2057.

[61] P. Sahariah, B.E. Benediktssdottir, M.A. Hjalmarsdottir, O.E. Sigurjonsson, K.K. Sorensen, M.B. Thygesen, K.J. Jensen, M. Masson, Impact of chain length on antibacterial activity and hemocompatibility of quaternary N-alkyl and n,n-dialkyl chitosan derivatives, Biomacromolecules 16(5) (2015) 1449-60.

[62] A.C. Anselmo, M.W. Zhang, S. Kumar, D.R. Vogus, S. Menegatti, M.E. Helgeson, S. Mitragotri, Elasticity of Nanopartides Influences Their Blood Circulation, Phagocytosis, Endocytosis, and Targeting, ACS nano 9(3) (2015) 3169-3177.

[63] M. Hoppert, Microscopic Techniques in Biotechnology, Wiley-VCH2003.

[64] Y. Wang, J. Zheng, Y. Tian, W. Yang, Acid degradable poly(vinylcaprolactam)-based nanogels with ketal linkages for drug delivery, J. Mater. Chem. B 3(28) (2015) 5824-5832. 
[65] C. Oliveira, A.J. Ribeiro, F. Veiga, I. Silveira, Recent Advances in Nucleic Acid-Based Delivery: From Bench to Clinical Trials in Genetic Diseases, Journal of Biomedical Nanotechnology 12(5) (2016) 841-862. [66] I.A. Khalil, K. Kogure, H. Akita, H. Harashima, Uptake pathways and subsequent intracellular trafficking in nonviral gene delivery, Pharmacological reviews 58(1) (2006) 32-45.

[67] S.E. Gratton, P.A. Ropp, P.D. Pohlhaus, J.C. Luft, V.J. Madden, M.E. Napier, J.M. DeSimone, The effect of particle design on cellular internalization pathways, Proceedings of the National Academy of Sciences of the United States of America 105(33) (2008) 11613-8.

[68] Y. Qiu, K. Park, Environment-sensitive hydrogels for drug delivery, Advanced drug delivery reviews 64 (2012) 49-60.

[69] F. Shi, J. Ding, C. Xiao, X. Zhuang, C. He, L. Chen, X. Chen, Intracellular microenvironment responsive PEGylated polypeptide nanogels with ionizable cores for efficient doxorubicin loading and triggered release, Journal of Materials Chemistry 22(28) (2012) 14168.

[70] S. Lou, S. Gao, W. Wang, M. Zhang, Q. Zhang, C. Wang, C. Li, D. Kong, Temperature/pH dual responsive microgels of crosslinked poly(N-vinylcaprolactam-co-undecenoic acid) as biocompatible materials for controlled release of doxorubicin, Journal of Applied Polymer Science 131(23) (2014) 4114641153.

[71] C. Sanson, C. Schatz, J.-F. Le Meins, A. Soum, J. Thévenot, E. Garanger, S. Lecommandoux, A simple method to achieve high doxorubicin loading in biodegradable polymersomes, Journal of Controlled Release 147(3) (2010) 428-435.

[72] A. Imaz, J. Forcada, N-vinylcaprolactam-based microgels for biomedical applications, Journal of Polymer Science Part A: Polymer Chemistry 48(5) (2010) 1173-1181.

[73] A. Cambon, A. Rey-Rico, D. Mistry, J. Brea, M.I. Loza, D. Attwood, S. Barbosa, C. Alvarez-Lorenzo, A. Concheiro, P. Taboada, V. Mosquera, Doxorubicin-loaded micelles of reverse poly(butylene oxide)poly(ethylene oxide)-poly(butylene oxide) block copolymers as efficient "active" chemotherapeutic agents, International journal of pharmaceutics 445(1-2) (2013) 47-57. 